HOHENHEIM DISCUSSION PAPERS

IN BUSINESS, ECONOMICS AND SOCIAL SCIENCES

Research Area INEPA

DISCUSSION PAPER 13-2017

\title{
SPATIAL DIFFERENGES IN STUNTING AND HOUSEHOLD AGRICULTURAL PRODUCTION IN SOUTH AFRICAH (RE-) EXAMINING THE LINKS USING NATIONAL PANEL SURVEY DATA
}

Steffen Otterbach University of Hohenheim

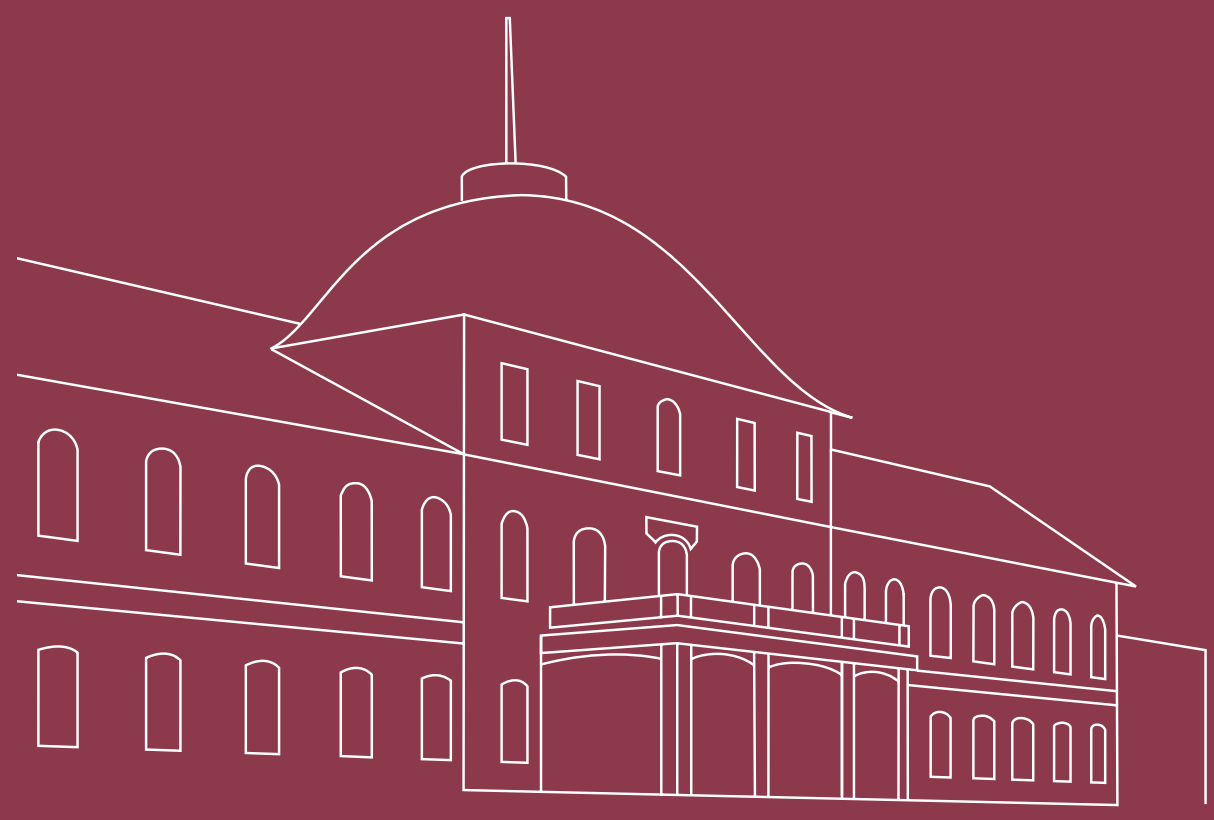

Michael Rogan Rhodes University 
Discussion Paper 13-2017

\title{
Spatial differences in stunting and household agricultural production in South African: (re-)examining the links using national panel survey data
}

\author{
Steffen Otterbach, Michael Rogan \\ Research Area "INEPA - Inequality and Economic Policy Analysis" \\ Download this Discussion Paper from our homepage: \\ https://wiso.uni-hohenheim.de/papers
}

ISSN 2364-2076 (Printausgabe)

ISSN 2364-2084 (Internetausgabe)

\begin{abstract}
Die Hohenheim Discussion Papers in Business, Economics and Social Sciences dienen der schnellen Verbreitung von Forschungsarbeiten der Fakultät Wirtschafts- und Sozialwissenschaften. Die Beiträge liegen in alleiniger Verantwortung der Autoren und stellen nicht notwendigerweise die Meinung der Fakultät Wirtschafts- und Sozialwissenschaften dar.
\end{abstract}

Hohenheim Discussion Papers in Business, Economics and Social Sciences are intended to make results of the Faculty of Business, Economics and Social Sciences research available to the public in order to encourage scientific discussion and suggestions for revisions. The authors are solely responsible for the contents which do not necessarily represent the opinion of the Faculty of Business, Economics and Social Sciences. 


\title{
Spatial differences in stunting and household agricultural production in South Africa: (re-)examining the links using national panel survey data
}

\author{
STEFFEN OTTERBACH ${ }^{1}$ AND MichaEL ROGAN ${ }^{2}$
}

\begin{abstract}
One explanation for the increasing prevalence of stunting in South Africa over the past 15 years while other development indicators have improved is that Big Food retail chains have been contributing to a low quality diet across the country, particularly in poor urban households. We thus use nationally representative longitudinal data (2008-2014) to trace 6 years of stunting's evolution among South African children, adolescents, and young adults aged 0-19, with particular attention to how the prevalence of under-nutrition differs between urban and rural areas and how the drivers of poor nutrition vary spatially. The results of our random-effects logistic regressions on the nutritional impact of household agricultural production suggest that, conditional on household income, subsistence farming is associated with a lower probability of stunting. Even more important, although under-nutrition retains a strong spatial component, once observable differences in living standards are controlled for, the higher tendency for children in deep rural households to suffer from (severe) stunting reverses.
\end{abstract}

Keywords: Stunting, height for age, malnutrition, anthropometric measures, subsistence farming, nutritional inequality, South Africa

JEL Classification: I14, I15, O15, O18, O55

\footnotetext{
${ }^{1}$ Institute for Health Care \& Public Management, University of Hohenheim, Stuttgart, Germany.

${ }^{2}$ Institute of Social and Economic Research (ISER), Rhodes University, Grahamstown, South Africa.
}

This analysis uses anonymized unit record data from the South African National Income Dynamics Study (NIDS, implemented and managed by the Southern Africa Labour and Development Research Unit (SALDRU) based at the University of Cape Town's School of Economics. Steffen Otterbach gratefully acknowledges the support provided by the Faculty of Business, Economics, and Social Sciences at the University of Hohenheim within the research area Inequality and Economic Policy Analysis. The authors would also like to thank Vadim Kufenko, Hamid Oskorouchi, Klaus Prettner, and Alfonso Sousa-Poza for valuable comments and discussion. 


\section{Introduction}

South Africa is one of only a handful of countries in which the prevalence of child stunting has increased over the period during which progress towards the Millennium Development Goals (MDGs) has been monitored (Hendriks, 2014; Hendriks et al., 2016). In fact, stunting, which serves as a marker for chronic malnutrition and/or poor maternal health, is more widespread in the country than acute malnutrition as measured by wasting (Faber and Wenhold, 2007). Not only does stunting affect about $20 \%$ of South African children aged 0-5 (Labadarios et al., 2008), but just over a third of the children who died in the country's hospitals between 2005 and 2009 were severely malnourished (Bamford, 2011). Stunting has a number of longterm impacts on health and may be irreversible in children older than two (Bhutta et al., 2008; Lo et al., 2017).

One of the puzzles in the South African context is that the prevalence of malnourishment and low nutritional diversity has persisted (or even increased) during the expansion of the government's social protection program (from 2002 onwards), which has improved household food security substantially (Devereux and Waidler, 2017; Hendriks, 2013; Hendriks, 2014; Pienaar and von Fintel, 2014; Ryan and Leibbrandt, 2015). This period also coincided with the introduction of the national program for prevention of mother-to-child HIV transmission (Barron et al., 2013), which would have been expected to decrease the prevalence of child stunting (Bailey et al., 1999). Major factors in explaining this persistence despite progress in other developmental indicators and expanded programs to address high levels of HIV infection include dietary diversity, food security, access to agricultural lands, food prices and differentials, and access to commercial food retailers. Hence, the South African literature (e.g., Walsh and van Rooyen, 2015) tends to focus on certain differences in nutritional status between urban and rural regions.

Three positive developments associated with the post-apartheid period-decreasing income poverty (related to an expanded social grant system), declining hunger levels, and improved access to service delivery - have been more pronounced in rural parts of South Africa (Pienaar and von Fintel, 2014; Zimbalist, 2017). Yet the available empirical evidence (Govender et al., 2017; Tibesigwa and Visser, 2015) is mixed in terms of how under-nutrition risk is likely to differ between urban and rural areas and how the drivers of poor nutrition may vary spatially. On the one hand, measures of dietary diversity suggest that households in deep rural areas tend to consume monotonous, low nutrition diets (Govender et al., 2017; Labadarios et al., 2011; Schmidt and Vorster, 1995), with some studies indicating poorer diversity in households farther away from supermarkets (Labadarios et al., 2011). Residents of rural areas also tend to have a 
lower intake of micronutrients than their urban counterparts (Mchiza et al., 2015). These findings are not necessarily surprising given that rural areas, and particularly those designated "Black homelands"3 during the apartheid era, are still defined by high levels of poverty and multiple deprivation (see Noble and Wright, 2013).

On the other hand, an emerging strand of the literature identifies access to Big Food ${ }^{4}$ and the higher prices of healthier food items, particularly in poor urban areas, as two of the problems accounting for the rise in non-communicable diseases (NCDs) in South Africa. In fact, a recent comprehensive review of dietary intake (Mchiza et al., 2015) points to evidence of a nutrition transition in the nation, with Black Africans in urban areas, particularly, reporting greater intakes of fat and added sugar. In addition to the well-documented public health challenges of obesity and under-nutrition in South Africa (Igumbor et al., 2012), some research also shows an association between higher income and the ongoing switch to a high fat diet with low nutritional value (MacIntyre et al., 2002). Certain of these trends coincided with a fairly remarkable increase between 2005 and 2010 in the consumption of processed, packaged, and otherwise unhealthy food (Igumbor et al., 2012). This increase has in turn been accompanied by the rapid expansion of large supermarket retailers into all segments of the South African market (D'Haese and van Huylenbroek, 2005; Igumbor et al., 2012; Kroll, 2016; Louw et al., 2007) including rural areas.

It therefore remains unclear whether the increase in child stunting is of greater concern for rural households because they are poorer and have less access to basic services (e.g., clean water and sanitation) and fresh food from large retailers or whether malnutrition may be mitigated in rural areas by lower exposure to Big Food and the nutrition transition's negative aspects, as well as by the ability to improve food diversity through food production. This latter issue of household agricultural production's role in addressing food security and improving nutrition is the subject of some debate in both the broader development and the South African literature. Whereas some work is relatively sceptical of these claims (Bradstock, 2005; De Swardt, 2003; Misselhorn, 2005; Palmer and Sender, 2006; Sender, 2002, 2012), a handful of studies presents direct evidence of household production's benefits for nutrition in South Africa (Hendriks, 2003; Kirsten et al., 1998; van Averbeke and Khosa, 2007).

\footnotetext{
${ }^{3}$ The 1951 Bantu Authorities Act established 10 areas as homelands for South Africa's Black African population. These homelands, now a part of South Africa, are often characterized as "deep rural", with higher levels of subsistence farming than other parts of the country (Noble and Wright, 2013; Pienaar and von Fintel, 2014; Rogan and Reynolds, 2017).

${ }^{4}$ This term refers to the large global food and beverage industry and its increasingly concentrated market power and distribution networks (PLoS Medicine Editors, 2012).
} 
One key gap in the literature, however, is how household production explains some of the spatial differences in child health and nutrition in South Africa. For example, Hendricks et al. (2016: 93), with specific reference to low nutritional levels in rural areas, suggest that "it is not known whether [the nutrition transition leading to stunting and obesity] is exaggerated in poor rural areas, and even less is understood about how infusions of cash in the form of grants and the introduction of other social protection measures interact with subsistence farming to influence household food security strategies and nutrition outcomes". Whereas recent research addresses the issue of household food security strategies (see von Fintel and Pienaar, 2016), no evidence is yet forthcoming on nutritional outcomes.

In this paper, therefore, we build on the extant literature by using six years of the nationally representative longitudinal South African National Income Dynamics Study (NIDS) to explore the association between child stunting, urban-rural differences, and household agricultural production. The advantage of this data set is that it includes an unusually rich set of socioeconomic and demographic variables, which enables us to isolate the associations between child stunting outcomes, spatial variables, and household agricultural activities.

We structure the remaining discussion as follows. Section 2 discusses key nutritional indicators (particularly, child stunting) in South Africa and identifies how these differ across the spatial categories used in national household surveys. Given our focus on agriculture and nutrition in South Africa's rural areas, the section also gives an overview of the spatial trends in poverty, food security, multiple deprivations, and service delivery during the post-apartheid period, as well as commercial retail's growing market penetration over the past decade and its link to poor health outcomes. It concludes by reviewing the international and South African literature on the link between household agricultural production and nutrition. Section 3 then describes the NIDS data and our key analytic variables and outlines our empirical strategy. Section 4 reports the results of two analytic phases; the first, a descriptive analysis of household agricultural production activities and trends in stunting (our key long-term nutrition indicator) by province and area type, and the second, a set of random effects logistic regressions identifying the association between child stunting and household production while controlling for a rich set of socioeconomic and demographic variables. Section five concludes the paper with a discussion of the results. 


\section{Literature}

\subsection{Child nutrition}

Despite recent progress in poverty reduction and improved food security, child health and malnutrition in South Africa remains a serious concern: although a middle income country, the prevalence of stunting (15.4\%) and severe stunting (3.8\%) is high (Shisana et al., 2013). Moreover, although it is not uncommon for the prevalence of stunting to improve more slowly than other developmental indicators (e.g., poverty and hunger) in the context of economic growth and rising income levels (Iannotti et al., 2009; World Bank, 2008; Ruel et al., 2013), South Africa is one of just 12 countries worldwide (and the only nation in the Southern African Development Community region) in which this prevalence actually increased ${ }^{5}$ in the 2000 s (Hendriks, 2014; Hendriks et al., 2016; Labadarios et al., 2008; Shisana et al., 2013).

Patterns of child stunting in South Africa have a strong spatial element, an issue on which we focus in the empirical section of our paper. In general, rates of stunting are highest in rural provinces and in the deep rural areas that have borne the brunt of apartheid era spatial planning in terms of both relative isolation and underdevelopment (Labadarios et al., 2011). The risk of stunting is also subject to gender and spatial differences, with boys from rural informal (nongovernmentally planned) areas having a higher risk (23.2\%) than boys from urban informal areas $(17 \%)$ but girls in urban informal areas having the highest stunting prevalence $(20.9 \%)$ followed by girls in rural informal areas (17\%) (Shisana et al., 2013: 206). These data, however, are from the South African National Health and Nutrition Examination Survey whose sample sizes are too small to allow statistical inference. The strongest claim that can be made, therefore, is that both boys and girls from urban formal areas experience significantly lower levels of stunting (Shisana et al., 2013). This conclusion also fits well with the broader South African literature, which suggests that children in deep rural areas are more likely to experience malnutrition and a lack of dietary diversity (see Labadarios et al., 2011).

\subsection{The nutrition transition}

A different perspective on stunting, and one that has received less attention in the South African literature, involves two related terms: "hidden hunger" and the already referenced "nutrition transition". Hidden hunger refers to a situation in which food availability is sufficient to prevent hunger (i.e., basic food security needs are met in terms of caloric intake) but food quality is low in terms of micronutrients and dietary diversity. The latter is exemplified by the Bangladesh context in which a rise in stunting prevalence alongside improved food security has

\footnotetext{
${ }^{5}$ Not all studies support this finding (e.g., May and Timaeus, 2014), but a recent review of the evidence for South Africa (Devereux and Waidler, 2017) suggests that, at the very least, there has been no progress in reducing child stunting since 1994 (the first year of democracy).
} 
probably resulted from persistent hidden hunger caused by poor quality diet and micronutrient deficiencies (Iannotti et al., 2009). Relatedly, the nutrition transition refers to a shift away from traditional foods to the so-called Western diet of "more energy-dense, processed foods, more foods of animal origin, and more added sugar, salt and fat" (Spires et al., 2016: 35).

One of the chief causes of stunted growth in South Africa's children from a nutritional perspective is the low diversity maize-based diet consumed in both rural and poor urban households (Hendriks et al., 2016). An additional aspect is this diet's association with the comorbidity of stunted growth and obesity in children (Hendriks et al., 2016). This association, which is relatively well-documented in the broader literature, is often referred to as the "double burden" of malnutrition (Igumbor et al., 2012; Lipton, 2013). Nonetheless, the evidence on the spatial features of both hidden hunger and the nutrition transition in South Africa remains inconclusive. On the one hand, some studies imply (Battersby and Peyton, 2014) or demonstrate (Igumbor et al., 2012) that the spike in unhealthy and highly processed food consumption is an urban phenomenon, with much of this work suggesting that the food transition and its associated negative outcomes have been concentrated in South Africa's urban areas (Battersby and Peyton, 2014). Igumbor et al. (2012: 6), for example, identify rapid urbanization, concentrated ownership of food production and distribution, and food trade globalization as key contributors to the nutrition transition in South Africa. One important feature of this phenomenon is that healthier food options tend to cost more (as much as 10 to 110 percent more according to some estimates) than unhealthier foods in large commercial supermarket chains (Battersby and Peyton, 2014; Igumbor et al., 2012; Spires et al., 2016; Temple et al., 2011). At the same time, some of these developments have been accompanied by rapid expansion of large supermarket retailers into all segments of the South African market (D'Haese and van Huylenbroek, 2005; Igumbor et al., 2012; Kroll, 2016; Louw et al., 2007), which expansion has itself coincided with a fairly remarkable increase between 2005 and 2010 in the consumption of processed, packaged, and otherwise unhealthy food (Igumbor et al., 2012).

On the other hand, some research claims that dietary diversity is far lower in rural provinces and in the tribal areas (Labadarios et al., 2011), linked partly to an income- monotonous diet association by which higher income ${ }^{6}$ households tend to have more diverse dietary intakes (Labadarios et al., 2011) while rural households are much more likely to be poor (Noble and Wright, 2013; Rogan and Reynolds, 2017). Moreover, although food prices have increased consistently over the past several years (Devereux and Waidler, 2017), they are highest in areas

\footnotetext{
${ }^{6}$ Obviously, this relation is not always linear, and there is also evidence that higher income and wealth levels are associated with a high fat, generally unhealthy, so-called modern diet (MacIntyre et al., 2002).
} 
where poor households are located (Labadarios et al., 2011). There is also evidence that, due partly to such government interventions as the subsidization and sometimes VAT exemption of staples like maize and bread, high energy basics are often cheaper than unprocessed foods (including fruits and vegetables) and thus more popular in poorer communities (Mchiza et al., 2015). Hence, contrary to the narrative of the nutrition transition being associated with supermarket purchased foods, other work demonstrates that households situated far away from supermarkets (e.g., those in rural areas) have lower levels of dietary diversity (Labadarios et al., 2011). When households in these rural areas (and to some extent in poor urban areas) do access commercial food retailers, they typically purchase unhealthy food, which may actually accelerate the nutrition transition and contribute to malnutrition through a lack of dietary diversity even in the face of access to supermarkets (Spires et al., 2016).

\subsection{Spatial trends in poverty, food security, and multiple deprivations}

Not only food consumption and nutrition but also important post-apartheid changes in poverty, food security, and material deprivation exhibit a strong spatial dimension. For example, the well-documented expansion of the government's non-contributory means-tested social grant system (in the form of cash transfers) was more concentrated in rural parts of South Africa. Under this scheme, between 1997 and 2012, the percentage of rural households receiving at least one monthly government cash transfer more than doubled while the percentage of urban grant receiving households increased by only 58 percent (Zimbalist, 2017). Largely as a result of this expansion and extension of the cash transfer program, poverty decreased relatively more in rural areas over the post-apartheid period (Zimbalist, 2017). One key outcome associated with this decrease is the drastic reduction in the percentage of households (both rural and urban) experiencing hunger. Whereas hunger levels have traditionally been higher in rural areas, a sharper reduction in rural areas (the former Black homelands in particular) from the early to mid-2000s, meant that, by 2008, the differences in hunger levels between homeland and non-homeland regions had been erased (Pienaar and von Fintel, 2014). Perhaps most significant, a key mechanism for the convergence of hunger levels across these area types has been the facilitation of household agricultural production by the expansion of cash transfers (von Fintel and Pienaar, 2016).

In addition to the reduction of income poverty and hunger, one of the most marked improvements in rural (relative to urban) areas has been the rapid increase in access to clean (piped) water, electricity, and telephones. Increases in access to these basic services have been far more substantial in rural areas (more than doubling in the case of electricity and telephone) than in urban areas where improvements have been more measured and from a much higher 
base (see Zimbalist, 2017). Yet despite this encouraging progress, the rural former homelands remain far poorer and suffer from a significantly higher level of multiple deprivations (including income, employment, education, living conditions, and health) relative to the rest of South Africa (Noble and Wright, 2013). In short, the spatial legacy of apartheid remains intact despite some important progress in service delivery and the injection of cash transfers into rural households (Noble and Wright, 2013; Pienaar and von Fintel, 2014).

\subsection{Household agricultural production and nutrition}

Given the progress in rural South Africa in poverty reduction and improved food security together with the potential role of household agricultural production (Pienaar and von Fintel, 2014; Rogan and Reynolds, 2017), the link between agriculture and nutrition is a natural focus in the context of high levels of child stunting. Nevertheless, internationally, the evidence on the impact of either household or small-scale subsistence agricultural production (Berti et al., 2004) or agricultural intervention (Ruel et al., 2013; World Bank, 2008) on child and maternal nutrition is inconclusive, making the former particularly the subject of long-time debate (Lunven, 1982; Rami'rez, 2002; Smitasiri, 2001; von Braun and Kennedy, 1986). Even in studies that do identify an association between subsistence agriculture and child anthropometry, the effects tend to be quite small (Ruel et al., 2013). Hence, in general, although these reviews (Pinstrup-Andersen, 2013; Ruel, 2001; Ruel et al., 2013; World Bank, 2008) outline a clear conceptual link between household agriculture and nutrition (see Ruel et al., 2013; World Bank, 2008), establishing an empirical association between household production activities or interventions and nutrition remains elusive.

Naturally, there are exceptions, although three of the most comprehensive studies showing an empirical link between household agricultural production and nutrition are by no means recent. For example, Shack et al. (1990), in their now seminal work on household agriculture and nutrition in Papua New Guinea, show that cash crop income allows households to supplement traditional diets with energy- and protein-dense purchased foods, which has a positive impact on child nutrition. Likewise, some of the more detailed empirical work demonstrating the link between subsistence agriculture and child nutrition, again in Papua New Guinea, associates both more intense and diverse small-scale agricultural activities and household income with improved child nutrition (Mueller et al., 2001a, 2001b). More recent evidence of a positive impact on nutrition comes from an evaluation of a homestead agricultural support package in Bangladesh (Iannotti et al., 2009).

South Africa, as a middle-income country, has relatively lower levels of subsistence agriculture than many of the developing countries addressed in the literature. Mueller et al. 
(2001), for example, note that about 85 percent of households in Papua New Guinea depend on subsistence farming. The empirical base for South Africa is also thin, with only a handful of studies attempting to demonstrate a link between household production and nutrition ${ }^{7}$. Perhaps the most detailed of these (Kirsten et al., 1998) is not only from two decades ago but based on only a small number of households (79) in one province. This research does, however, provide evidence that household agricultural production improves nutrition but only in households for which agriculture is a serious activity, which implies that community gardens and purely subsistence agricultural activities are not linked to improved nutrition (see also Hendriks, 2003). Such a conclusion inherently obscures the possibility of a dual causality in which some of the more successful households at farming may also have higher levels of nutrition and a more diverse diet.

Other work from South Africa, although more recent, is based on samples that are not only small but very narrow in geographic focus (Adekunle et al., 2014; Hendriks, 2003; Modi et al., 2006; van Averbeke and Khosa, 2007). The most recent (Hendriks et al. 2016) does provide some evidence that household production is associated with greater dietary diversity, but the bivariate analysis (again based on a small sample size) is methodologically weak. Nonetheless, the empirical work for South Africa, although limited, does provide some indication that subsistence agriculture is associated either directly or indirectly with a higher intake of nutrient dense foods when households produce these foods themselves or grow staples and then redirect household resources towards the purchase of animal products and fresh fruit and vegetables (Govender et al., 2017; Schmidt and Vorster, 1995; van Averbeke and Khosa, 2007). To date, however, there is no analysis of the link between child stunting (or the broader issue of nutrition) and household production based on a large scale nationally representative survey. As a result, the relative risks (and determinants) of malnutrition in urban and rural areas remain largely unexplored.

\section{Methodology}

\subsection{Data}

Our dataset comprises the first four waves of South Africa's first nationally representative panel survey (SALDRU, 2016a, 2016b, 2016c, 2016d), the South African National Income Dynamics Study (NIDS). ${ }^{8}$ The initial wave (2008) was administered to about 28,000 individuals in 7,300 households, designated as continuing sample members (CSM), a group that includes

\footnotetext{
${ }^{7}$ The empirical basis for the association between household production and food security (Aliber and Hart, 2009; Devereux and Waidler, 2017; Pienaar and von Fintel, 2014; Rogan and Reynolds, 2017) is much stronger.

${ }^{8}$ For more information on the NIDS, see Chinhema et al. (2016).
} 
children born or adopted into the original survey households. In the subsequent waves, administered every two years, new individuals entered the survey if and only if they were coresiding with an original CSM and were therefore labelled temporary sample members (TSM). Because NIDS is designed to follow CSMs and their co-residents during the time of cohabitation, the sample size increases over time, to around 34,000, 37,000, and 42,000 individuals in waves 2,3 , and 4 , respectively.

\subsection{Sample}

The NIDS provides height for age $z$-scores, the central measure for our study, for children, adolescents, and young adults aged 0 to 19 years. We thus limit our analysis to this age group for initial samples of 9,321, 8,485, 12,635, and 15,384 individuals in waves 1, 2, 3, and 4, respectively.

\subsection{Anthropometric measurement of stunting}

With the assistance of a qualified nurse, fieldworkers received training on how to measure height and other anthropometric factors, including how to measure babies' and young children's ( $<24$ months) height in the recumbent position. Two height measurements were taken and averaged, and if these differed by more than one centimeter, a third measure was taken to calculate the height for age $z$-scores. These latter were based on age in days and on the WHO international child growth standards (WHO, 2006) for children aged 5 and younger and the WHO standards for children and adolescents (De Onis et al., 2007) for individuals over 5. (Severe) stunting was defined as (3) 2 standard deviations below the growth standard median, with $z$-scores of $>6$ and $<-6$ considered biologically implausible and excluded from the analysis. Our dependent variable is thus binary (yes/no), indicating whether a respondent is or is not (severely) stunted.

\subsection{Explanatory variables}

One of our main explanatory variables is aggregated household income, used to reflect a household's regular monthly income net of taxes. The derived income variable is an aggregate of different income sources, including labour market income; government grants and other government payments (e.g., unemployment insurance fund, workmen's compensation); interest, dividend, and rental income; remittances; subsistence agriculture; and imputed rental income from owner-occupied houses. Total household income is deflated using the monthly national headline consumer price index with November 2014 as the base month (Statistics South Africa, 2017). Lastly, we construct the natural logarithm of real equivalized net household income, adjusted to household structure using the modified OECD scale (Hagenaars et al., 1994). 
Our main variable of interest is a dummy variable indicating whether a household is engaged in farming activities that are not part of paid employment, such as growing food or raising livestock. Also important is geographic classification of residence, provided in NIDS based on the 2011 census (SALDRU, 2014), which also describes infrastructure, level of service delivery, and market access, as well as density of and distance to hospitals and doctors. We therefore include a set of dummy variables for whether the respondent lives in a traditional, farming, or urban area (reference category). Whereas traditional areas are closely associated with the Black homelands of the apartheid era and remain under the jurisdiction of traditional leaders (see Noble and Wright, 2013), urban settlements are continuously built-up areas such as cities, towns, townships, small towns, and hamlets. Farming areas are locations in which land is allocated and used for commercial farming.

In addition to household income, we also control for several socio-economic and sociodemographic variables at the individual and household level, including gender, population group, gender and educational level of household head, and number of employed persons in the household. We also control at the household level for living conditions that might directly affect respondent and child health, including diarrheal diseases caused by inadequate access to water and sanitation (Prüss-Ustün et al., 2014). The model thus includes variables for whether the respondent lives in a household with access to a flush toilet, tap water, electricity, and whether refuse and rubbish are removed on a regular basis.

\subsection{Econometric analysis}

Our binary dependent variable requires a non-linear probability model, which can also account for the longitudinality of the data. At the same time, our interest in multiple timeconstant explanatory variables (e.g., population group and gender) precludes the use of a fixedeffects (FE) logistic estimator. Moreover, as FE logistic regressions are estimated via conditional maximum likelihood, the estimation sample is limited to observations exhibiting within-person changes in the response variable which contribute to this likelihood. Given that "almost all stunting takes place within the first 1,000 days after conception" (Black et al., 2013) and may be irreversible later in life, such within-person changes in stunting are almost exclusively observable only in babies and very young children ( $<24$ months). Given our additional interest in the prevalence and determinants of stunting in older individuals (aged 0 to 19) - for which we expect no substantial within-person changes in the response variable we estimate random effects logistic regressions that allow inclusion of both time-variant and time-constant variables. These regressions also allow for unobserved heterogeneity but with the 
stronger assumption of no correlation with our explanatory variables. Our random effects logistic regression model can thus be formulated as

$$
\ln \left(\frac{\operatorname{Pr}\left(y_{i t} \mid \beta, x_{i t}, \gamma, z_{i}, \theta_{t}, u_{i}\right)}{1-\operatorname{Pr}\left(y_{i t} \mid \beta, x_{i t}, \gamma, z_{i}, \theta_{t}, u_{i}\right)}\right)=\beta_{0}+\beta x_{i t}+\gamma z_{i}+\theta_{t}+u_{i}
$$

where $\mathrm{x}_{\mathrm{it}}$ is the time-variant and $\mathrm{z}_{\mathrm{i}}$ the time-constant explanatory variables, $\theta_{\mathrm{t}}$ denotes a set of survey year indicators, and $\mathrm{u}_{\mathrm{i}}$ is the unit-specific error term. Unlike panel estimators for continuous dependent variables, binary response models focus on probabilities; they are thus inherently stochastic and seldom contain an idiosyncratic error ( $\left.\varepsilon_{i t}\right)$ that varies over time (Andreß et al., 2013).

\section{Results}

One important initial insight from the weighted descriptive statistics for the prevalence of (severe) stunting (both pooled sample and disaggregated by survey year and province) is that the nationwide prevalence decreased substantially from $17 \%$ in 2008 to $12 \%$ in 2014 but increased to about $20 \%$ in both 2010 and 2012 (see Table 1). The table also reveals substantial differences in both levels and trends of stunting across provinces. Although in most provinces the prevalence of (severe) stunting decreased between 2008 and 2014, it remained at high levels in the largely rural provinces of the Northern and Eastern Cape, the Free State, and the North West, with an actual increase in these latter two. Although the 2008-2012 increases in both stunting and severe stunting conform closely to the findings from key studies on nutrition in South Africa, the noticeable decrease in 2014 is something of an anomaly. ${ }^{9}$

Focusing on the descriptive trends in the 2008-2012 period, the relative increases in stunting and severe stunting are similar in both the deep rural (traditional) and urban areas at 16 and 19 percent, and 35 and 36 percent, respectively. These increases, however, grew from a much higher base in the traditional areas. The table also suggests that the convergence in the

\footnotetext{
${ }^{9}$ This anomaly is not necessarily a problem for our empirical strategy because we are interested in the relation between subsistence agriculture and stunting. We do note, however, that there are several plausible explanations for the relatively rapid decrease in stunting prevalence between the last two waves of NIDS. First, the outcomes could reflect survey attrition which, if correlated with stunting risk itself, would not be corrected by the poststratification survey weights. Second, the decrease could also reflect delayed reaction to the social grant expansion and corresponding decreases in hunger levels. It is likely, for example, that a number of CSMs from the panel survey moved out of the 0-19 cohort during the 2014 wave and did not benefit from the expanded social protection system at ages $0-5$. They were thus more likely to be at risk for malnutrition and hunger at crucial stages in their development.
} 
prevalence of malnutrition (proxied by stunting) between rural and urban areas did not occur in the same way as the well-documented convergence in hunger levels.

Table 1 about here

The weighted descriptive statistics for all analytic covariates over the six-year time span further reveal a slight increase in real equivalized household income, from about R3,400 in 2008 to R3,900 in 2014 (see Table 2). The share of the population involved in subsistence farming decreased substantially ( $24 \%$ in 2008 ) in the two waves subsequent to the initial wave $(11 \%$ and $10 \%)$ and then increased again (17\%) in 2014. At the same time, the geographic classification reflects a migration tendency from traditional and farming areas to the cities. For example, in 2008, the fraction of the sample living in traditional (urban) areas was 44\% (51\%), which decreased (increased) to $41 \%(56 \%)$ in 2014 . Focusing specifically on changes over the six-year time span further reveals improved educational levels, with a decreasing share of household heads who have no or only some primary schooling and an increased enrolment in secondary schooling and higher education. At the same time, in line with the well-documented expansion of basic services over the 2008-2014 period, we also note improved living conditions in terms of access to tap water, a flush toilet, electricity, and a waste disposal system. Nonetheless, the average number of employed persons in the household increased only marginally, reflecting the persistently high levels of unemployment and large dependency on social grants in the country.

Table 2 about here

For the multivariate random effects logistic regression models, we run two different specifications for each stunting measure (Table 3). For specifications 1 and 2 (stunting), the coefficients on household income are significant and negative, supporting the expectation that higher income will be associated with a lower probability of stunting. That is, although it remains unclear whether and to what extent higher income leads to healthier and higher priced food choices, income is the main determinant of access to food and a greater variety of food choices. As regards the variable of most interest to this study, involvement in subsistence farming, we again find a significantly negative impact on the probability of stunting, which supports the intuitive assumption that agricultural involvement improves access to food by providing an additional food source. At the same time, although it is less clear whether and to 
what extent subsistence farming may lead to greater dietary diversity, the negative association between subsistence farming and stunting probability could indicate a diet that is, to a lesser degree, based on either packaged or processed food or a monotonous diet devoid of fresh food.

Given that deep rural traditional areas are associated with high levels of poverty, unemployment, and material deprivation, it is not surprising that we initially find a positive and significant coefficient for specification 1 ; that is, a higher probability of stunting in traditional areas even after income is controlled for. Once we add in controls for living conditions (specification 2), however, the direction of the association reverses while still remaining significant. In other words, once we control for the detrimental effects of poor living conditions, living in traditional areas poses a significantly lower risk of stunting. Most important, the size and direction of the association between subsistence farming and stunting remains the same in the second specification. Thus, once income, living conditions, and a large set of covariates are controlled for, involvement in agricultural activities for household consumption is a significant protector against stunting. Taken together, these results are consistent with the hypothesis that rural households may be less exposed to the nutrition transition and the negative aspects of Big Food. They may even be able to enhance their dietary diversity through access to wild food.

The analytic results further suggest that females are less likely to be stunted whereas gender of the household head appears to have no statistically significant effect. As regards population groups, Whites have a significantly lower probability of being stunted than Black Africans (reference group), Coloureds are significantly more likely to be stunted, while Indians/Asians exhibit a non-significant negative effect. The probability of stunting also decreases with education level, significantly so for a household head with some type of secondary schooling or higher education compared to the no schooling reference but only insignificantly for primary schooling.

In the case of severe stunting (specifications 3 and 4), for most control variables, the direction and size of the estimated coefficients are very similar to those using (non-severe) stunting as the dependent variable (see Table 3). However, certain confounding variables - such as living in a traditional or farming area, having secondary schooling, or having access to a flush toilet - are not significant in specification 4. In both specifications, being White has a positive but insignificant coefficient. It is also important to note that rho - the total error variance due to unobserved heterogeneity - is much lower in the severe stunting specifications than in those for (non-severe) stunting (about 38\% vs. 53\%). Rho can also be interpreted as the serial correlation that remains in the dependent variable after all explanatory variables are controlled for because of person-specific unobserved heterogeneity (Andreß, Golsch, and 
Schmidt, 2013: 241). More broadly, however, the key finding from the stunting specifications is also observable in the severe stunting specifications: once living conditions (i.e., access to basic services) are controlled for, the higher risk of severe stunting in deep rural traditional areas disappears. At the same time, the apparent protective effect of subsistence agriculture remains in both severe stunting specifications.

Table 3 about here

\section{Discussion and Conclusions}

Not only is stunting endemic in South Africa but there is sparse evidence of any improvement over the past 20 years. This lack of progress is particularly worrying given that South Africa, as a middle-income country, has made important strides over recent years in service delivery, access to clean water, expansion of social security protection, and reduction of hunger levels. South Africa even ranks highest on the Hunger and Nutrition Commitment Index Africa $^{10}$ for its efforts to combat food insecurity and undernutrition. Why then has stunting persisted and possibly even worsened despite these efforts and widespread recognition of the condition's long-term developmental impacts (Lo et al., 2017)?

Some of the more recent contributions to the South African literature argue that the problem is not simply the lack of food associated with stunting and other forms of malnutrition or undernourishment but rather the quality of the food available to households in poor areas (both urban and rural). This work is particularly interested in the role of Big Food in creating a food system in South Africa that offers poorer households affordable food products with very little nutritional value (Igumbor et al., 2012; Ledger, 2016). To date, however, the empirical evidence for these claims remains both thin and inclusive given some research claims that access to large supermarket chains protects against under-nutrition by improving dietary diversity.

This paper adds to the literature by exploring the prevalence of stunting through the lens of spatial differences and subsistence agriculture, both of which we propose as crude proxies for the level of interaction with large supermarket retailers. Our key finding is that once household income and a range of other covariates are controlled for, children, adolescents, and young adults in households that engage in subsistence agriculture are significantly less likely to suffer

\footnotetext{
${ }^{10} \mathrm{http}$ ://africa.hancindex.org/
} 
from stunting or severe stunting. Although only suggestive, these findings are consistent with the argument that households that purchase their food from large retailers are more likely to experience the negative effects of the nutrition transition.

Nevertheless, even after multiple factors are controlled for, the risk of stunting remains higher in deep rural areas - particularly those demarcated as Black homelands under apartheid. In fact, it is only when we control for access to basic services like sanitation and piped water that the higher risk of stunting in rural areas reverses (cf. Devereux and Waidler, 2017; Hammer and Spears, 2016; May and Timaeus, 2014; Mulmi et al., 2016; Vyas et al., 2016). This finding is crucial in its implication that once we control for the more obvious and observable sources of deprivation for rural households, children in these households are actually at a significantly lower risk of stunting than their urban counterparts.

In terms of our contribution to the larger body of international literature on small-scale agriculture, we claim merely that our findings suggest ways in which households disconnected from the Big Food system in South Africa may be partially protected from reliance on the empty high energy calorie foods that are generally affordable (see Ledger, 2016). Hence, while careful not to promote an over-romanticized notion that subsistence agriculture or home gardening is the solution to undernutrition and its effects in South Africa, we cannot ignore the possibility that such activities could play into this solution. Unfortunately, as yet, South Africa has no formal food security policy, with any legislative mention tending to be abstract and disjointed (Hendriks, 2014) and related policy to date being somewhat fragmented, with interventions falling across sectors from education (in the form of school feeding schemes) to social development to agriculture. Policy also tends to frame nutrition as a "rural and food production issue" (Hendriks, 2014; Spires et al., 2016: 38) even though a subsistence farming solution places the responsibility for nutrition largely on poor rural households while detracting from larger development and public health issues. Not only have no attempts yet been made to formally evaluate the existing food programs, but interventions frequently fail to differentiate between the indicators of nutrition and those of basic hunger. For example, whereas cash transfers play a large role in improving food security in South Africa (Devereux and Waidler, 2017), their monetary amounts are likely to be too small (and decreasing in real terms) to significantly improve dietary quality.

Hence, even though policies that make land available for small scale food production in South Africa certainly have their proponents (Labadarios et al., 2011), our findings are only broadly supportive of such an approach. In fact, despite pointing to the important role of subsistence agriculture, our analysis identifies several other factors capable of explaining urban 
and rural area differences. One such difference is the likelihood of both stunting and severe stunting being higher in deep rural areas, a tendency that holds in our descriptive statistics but reverses when our regressions control for the multiple deprivations of income, education, and access to basic services. This observation is crucial because it implies a negative association between stunting risk and living in households located farther away from retail supermarket chains. Thus, rather than supporting the controversial idea of home gardens and similar subsistence activities as a policy solution to hunger and malnutrition, our results suggest that these activities may serve as a proxy for disconnection from a Big Food system that is actually quite harmful for poorer households. 


\section{References}

Adekunle, O.O., Monde, N., Agholor, I., Odeyemi, A.S., 2014. The role of home gardens in household food security in Eastern Cape: a case study of three villages in Nkonkobe Municipality. J. Agric. Sci. 6, 67-76.

Aliber, M., Hart, T., 2009. Should subsistence agriculture be supported as a strategy to address rural food insecurity? Agrekon 48, 434-458.

Andreß, H.-J., Golsch, K., Schmidt, A.W., 2013. Applied Panel Data Analysis for Economic and Social Surveys. Springer, Berlin.

Bailey, R., Kamenga, M., Nsuami, M., Nieburg, P., St Louis, M., 1999. Growth of children according to maternal and child HIV, immunological and disease characteristics: a prospective cohort study in Kinshasa, Democratic Republic of Congo. Int. J. Epidemiol. 28, 532-540.

Bamford, L., 2011. An overview of five years of child PIP data, in: Stephen, C., Bamford, L., Patrick, M., Wittenberg, D. (Eds.), Saving Children 2009: Five Years of Data. A Sixth Survey of Child Health Care in South Africa. Tshepesa Press, MRC, CDC, Pretoria.

Barron, P., Pillay, Y., Doherty, T., Sherman, G., Jackson, D., Bhardwaj, S., Robinson, P., Goga, A., 2013. Eliminating mother-to-child HIV transmission in South Africa. Bull. World Health Organ. 91, 70-74.

Battersby, J., Peyton, S., 2014. The geography of supermarkets in Cape Town: supermarket expansion and food access. Urban Forum 25, 153-164.

Berti, P., Krasevec, J., Fitzgerald, S., 2004. A review of the effectiveness of agriculture interventions in improving nutrition outcomes. Pub. Health Nutr. 75, 599-609.

Bhutta, Z., Ahmed, T., Black, R., Cousens, S., Dewey, K., Giugliani, E., Haider, B., Kirkwood, B., Morris, S., Sachdev, H., Shekar, M., 2008. What works? Interventions for maternal and child undernutrition and survival. Lancet 371, 417-440.

Black, R.E., Victora, C.G., Walker, S.P., Bhutta, Z.A., Christian, P., De Onis, M., Ezzati, M., Grantham-McGregor, S., Katz, J., Martorell, R., 2013. Maternal and child undernutrition and overweight in low-income and middle-income countries. Lancet 382, 427-451.

Bradstock, A., 2005. Changing livelihoods and land reform: evidence from the Northern Cape province of South Africa. World Development 33, 1979-1992.

Chinhema, M., Brophy, T., Brown, M., Leibbrandt, M., Mlatsheni, C., Woolard, I., 2016. National Income Dynamics Study Panel User Manual. Southern Africa Labour and Development Research Unit, Cape Town

D'Haese, M., van Huylenbroek, G., 2005. The rise of supermarkets and changing expenditure patterns of poor rural households case study in the Transkei area, South Africa. Food Policy 30, 97-113.

De Onis, M., Onyango, A., Borghi, E., Siyam, A., Nishida, C., Siekmann, J., 2007. Development of a WHO growth reference for school-aged children and adolescents. Bull. World Health Organ. 85, 660-667.

De Swardt, C., 2003. Unravelling chronic poverty in South Africa some food for thought. International Conference on Chronic Poverty Research, University of Manchester.

Devereux, S., Waidler, J., 2017. Why does malnutrition persist in South Africa despite social grants?, Food Security SA Working Paper No.001. DST-NRF Centre of Excellence in Food Security, South Africa. 
Faber, M., Wenhold, F., 2007. Nutrition in contemporary South Africa. Water SA 33, 393-400.

Govender, L., Pillay, K., Siwela, M., Modi, A., Mabhaudhi, T., 2017. Food and nutrition insecurity in selected rural communities of KwaZulu-Natal, South Africa: linking human nutrition and agriculture. Int. J. Environment. Res. Pub. Health 14, 1-21.

Hagenaars, A.J., De Vos, K., Zaidi, A.M., 1994. Poverty statistics in the late 1980s: research based on micro-data. Office for Official Publications of the European Community, Luxemburg.

Hammer, J., Spears, D., 2016. Village sanitation and child health: effects and external validity in a randomized field experiment in rural India. J. Health Econ. 48, 135-148.

Hendriks, S., 2003. The potential for nutritional benefits from increased agricultural production in rural KwaZulu-Natal. S. Afr. J. Agr. Ext. 32, 28-44.

Hendriks, S., 2013. South Africa's National Development Plan and New Growth Path: reflections on policy contradictions and implications for food security. Agrekon 52, 1-17.

Hendriks, S., 2014. Food security in South Africa: status quo and policy imperatives. Agrekon 53, 1-24.

Hendriks, S., Viljoen, A., Marais, D., Wenhold, F., McIntyre, A., Ngidi, M., van der Merwe, C., Annandale, J., Kalaba, M., Stewart, D., 2016. The current rain-fed and irrigated production of food crops and its potential to meet the all-year-round nutritional requirements of rural poor people in North West, Limpopo, KwaZulu-Natal and the Eastern Cape, A report to the Water Research Commission. Institute for Food, Nutrition and Well-being, University of Pretoria, Pretoria.

Iannotti, L., Cunningham, K., Ruel, M., 2009. Improving diet quality and micronutrient nutrition: homestead food production in Bangladesh, IFPRI Discussion Paper No. 00928. International Food Policy Research Institute (IFPRI), Washington, DC.

Igumbor, E., Sanders, D., Puoane, T., Tsolekile, L., Schwarz, C., Purdy, C., Swart, R., Durao, S., Hawkes, C., 2012. "Big Food", the consumer food environment, health, and the policy response in South Africa. PLOS Medicine 9, 1-7.

Kirsten, J., Townsend, R., Gibson, C., 1998. Determination of agricultural production to household nutritional status in KwaZulu-Natal, South Africa. Development Southern Africa 15, 573-587.

Kroll, F., 2016. Foodways of the poor in South Africa: how value-chain consolidation, poverty and cultures of consumption feed each other, Working Paper No. 36. PLAAS, UWC and Centre of Excellence on Food Security, Cape Town.

Labadarios, D., Steyn, N., Nel, J., 2011. How diverse is the diet of adult South Africans? Nutr. J. 10, 1-11.

Labadarios, D., Swart, R., Maunder, E., Kruger, H., Gericke, G., Kuzwayo, P., Ntsie, P., Steyn, N., Schloss, I., Dhansay, M., Jooste, P., Dannhauser, A., Nel, J., Molefe, D., Kotze, T., 2008. National Food Consumption Survey-Fortification Baseline (NFCS-FB-I) South Africa, 2005. S. Afr. J. Clin. Nutr. 21, 245-300.

Ledger, T., 2016. An Empty Plate: Why We Are Losing the Battle for Our Food System. Jacana Media, Johannesburg.

Lipton, M., 2013. Staples production: efficient "subsistence" smallholders are key to poverty reduction, development, and trade, UNCTAD Global Commodities Forum 2013: Recommitting to commodity sector development as an engine of economic growth and poverty reduction, Geneva. 
Lo, S., Das, P., Horton, R., 2017. Early childhood development: the foundation of sustainable development. Lancet 389, 9-11.

Louw, A., Vermeulen, H., Kirsten, J., Madevu, H., 2007. Securing small farmer participation in supermarket supply chains in South Africa. Development Southern Africa 24, 539-551.

Lunven, P., 1982. The nutritional consequences of agricultural and rural development projects. Food Nutr. Bull. 4, 17-22.

MacIntyre, U., Kruger, H., Venter, C., Vorster, H., 2002. Dietary intakes of an African population in different stages of transition in the North West Province, South Africa: the THUSA study. Nutr. Res. 22, 239-256.

May, J., Timaeus, 2014. Inequities in under-five child nutritional status in South Africa: what progress has been made? Development Southern Africa 31, 761-774.

Mchiza, Z., Steyn, N., Hill, J., Kruger, A., Schönfeldt, H., Nel, J., Wentzel-Viljoen, E., 2015. A review of dietary surveys in the adult South African population from 2000 to 2015. Nutrients 7, 8227-8250.

Misselhorn, A., 2005. What drives food insecurity in southern Africa? A meta-analysis of household economy studies. Global Environmental Change 15, 33-43.

Modi, M., Modi, A., Hendriks, S., 2006. Potential role for wild vegetables in household food security: a preliminary case study in Kwazulu-Natal, South Africa. Afr. J. Food, Agr., Nutr. Dev. 6, 1-13.

Mueller, I., Vounatsou, P., Allen, B., Smith, T., 2001a. Spatial patterns of child growth in Papua New Guinea and their relation to environment, diet, socio-economic status and subsistence activities. Ann. Hum. Biol. 28, 263-280.

Mueller, I., Vounatsou, P., Smith, T., Allen, B., 2001b. Subsistence agriculture and child growth in Papua New Guinea. Ecol. Food Nutr. 40, 367-395.

Mulmi, P., Block, S., Shively, G., Masters, W., 2016. Climatic conditions and child height: sexspecific vulnerability and the protective effects of sanitation and food markets in Nepal. Econ. Hum. Biol. 23, 63-75.

Noble, M., Wright, G., 2013. Using indicators of multiple deprivation to demonstrate the spatial legacy of apartheid in South Africa. Soc. Indicat. Res. 112, 187-201.

Palmer, K., Sender, J., 2006. Prospects for on-farm self-employment and poverty reduction: an analysis of the South African Income and Expenditure Survey 2000. J. Contemp. Afr. Stud. 24, 347-376.

Pienaar, L., von Fintel, D., 2014. Hunger in the former apartheid homelands: determinants of convergence one century after the 1913 land act. Agrekon 53, 38-67.

Pinstrup-Andersen, P., 2013. Can agriculture meet future nutrition challenges? Eur. J. Dev. Res. $25,5-12$.

PLoS Medicine Editors, 2012. PLoS Medicine Series on Big Food: The Food Industry Is Ripe for Scrutiny. PLoS Medicine 9, e1001246.

Prüss-Ustün, A., Bartram, J., Clasen, T., Colford, J.M., Cumming, O., Curtis, V., Bonjour, S., Dangour, A.D., De France, J., Fewtrell, L., 2014. Burden of disease from inadequate water, sanitation and hygiene in low-and middle-income settings: a retrospective analysis of data from 145 countries. Trop. Med. Int. Health 19, 894-905. 
Rami'rez, R., 2002. The effectiveness of small-scale agriculture interventions on household food security: a review of the literature, a report prepared for the Canadian FoodGrains Bank, Interpares, Partners for Development, Oxfam Canada, the Canadian International Development Agency and the International Development Research Centre, Ottawa.

Rogan, M., Reynolds, J., 2017. Food poverty, hunger and household production in rural Eastern Cape households, REDI 3x3 Working Paper No. 29. Southern Africa Labour and Development Research Unit (SALDRU), University of Cape Town, Cape Town.

Ruel, M., 2001. Can food-based strategies help reduce Vitamin A and iron deficiencies? A review of recent evidence, Food Policy Review No. 5. International Food Policy Research Institute (IFPRI), Washington, DC.

Ruel, M., Alderman, H., Maternal and Child Nutrition Study Group, 2013. Nutrition-sensitive interventions and programmes: how can they help to accelerate progress in improving maternal and child nutrition? Lancet 382, 536-551.

Ryan, J., Leibbrandt, M., 2015. Multidimensional food insecurity measurement, Southern Africa Labour and Development Research Unit Working Paper No. 160. SALDRU, University of Cape Town, Cape Town.

SALDRU, 2014. Inclusion of Census 2011 geographic variables in NIDS. Southern Africa Labour and Development Research Unit (SALDRU), University of Cape Town, Cape Town.

SALDRU, 2016a. National Income Dynamics Study 2008, Wave 1, Version 6.1 ed. DataFirst, Cape Town.

SALDRU, 2016b. National Income Dynamics Study 2010-2011, Wave 2, Version 3.1 ed. DataFirst, Cape Town.

SALDRU, 2016c. National Income Dynamics Study 2012, Wave 3 Version 2.1 ed. DataFirst, Cape Town.

SALDRU, 2016d. National Income Dynamics Study 2014 - 2015, Wave 4 Version 1.1 ed. DataFirst, Cape Town.

Schmidt, M., Vorster, H., 1995. The effect of communal vegetable gardens on nutritional status. Develop. S. Afr. 12, 713-724.

Sender, J., 2002. Women's struggle to escape rural poverty in South Africa. J. Agrar. Change 2, 1-49.

Sender, J., 2012. Fictions and elephants in the rondawel: a response to a brief chapter in South Africa's National Development Plan. Transformation 78, 98-114.

Shack, K., Grivetti, L., Dewey, K., 1990. Cash cropping, subsistence agriculture, and nutritional status among mothers and children in lowland Papua New Guinea. Soc. Sci. Med. 31, 61-68.

Shisana, O., Labadarios, D., Rehle, T., Simbayi, L., Zuma, K., Dhansay, A., Reddy, P., Parker, W., Hoosain, E., Naidoo, P., Hongoro, C., Mchiza, Z., Steyn, N., Dwane, N., Makoae, M., Maluleke, T., Ramlagan, S., Zungu, N., Evans, M., Jacobs, L., Faber, M., SANHANES-1 Team, 2013. South African National Health and Nutrition Examination Survey (SANHANES-1). HSRC Press, Cape Town.

Smitasiri, S., 2001. A comment on how the nutritional impact of agricultural innovations can be enhanced. Food Nutr. Bull. 21, 503-506.

Spires, M., Delobelle, P., Sanders, D., Puoane, T., Hoelzel, P., Swart, R., 2016. Diet-related non-communicable diseases in South Africa: determinants and policy responses, in: Padarath, 
A., King, J., Mackie, E., Casciola, J. (Eds.), South African Health Review 2016. Health Systems Trust, Durban, pp. 35-42.

Statistics South Africa, 2017. Monthly national headline consumer price index, http://www.statssa.gov.za/publications/P0141/CPIHistory.pdf, Pretoria.

Temple, N., Steyn, N., Fourie, J., de Villiers, A., 2011. Price and availability of healthy food: a study in rural South Africa. Nutrition 27, 55-58.

Tibesigwa, B., Visser, M., 2015. Small-scale subsistence farming, food security, climate change and adaptation in South Africa: male-female headed households and urban-rural nexus, ERSA Working Paper No. 527. Economic Research Southern Africa (ERSA), Cape Town.

van Averbeke, W., Khosa, T., 2007. The contribution of smallholder agriculture to the nutrition of rural households in a semi-arid environment in South Africa. Water SA 33, 413-418.

von Braun, J., Kennedy, E., 1986. Commercialization of subsistence agriculture: income and nutritional effects in developing countries, Working Paper on the Commercialization of Agriculture and Nutrition No. 1. International Food Policy Research Institute, Washington, DC.

von Fintel, D., Pienaar, L., 2016. Small-scale farming and hunger: the enabling role of social assistance programmes in South Africa's former homelands, ERSA Working Paper No. 647. Economic Research Southern Africa (ERSA), Cape Town.

Vyas, S., Kov, P., Smets, S., Spears, D., 2016. Disease externalities and net nutrition: evidence from changes in sanitation and child height in Cambodia, 2005-2010. Econ. Hum. Biol. 23, 235-245.

Walsh, C., van Rooyen, F., 2015. Household food security and hunger in rural and urban communities in the Free State Province, South Africa. Ecol. Food Nutr. 54, 118-137.

WHO, 2006. WHO Child Growth Standards: Length/height-for-age, weight-for-age, weightfor-length, weight-for-height and body mass index-for-age: methods and development. World Health Organization, Geneva.

World Bank, 2008. From agriculture to nutrition: pathways, synergies and outcomes, Report No. 40196-GLB., World Bank, Washington, DC.

Zimbalist, Z., 2017. Analysing post-apartheid poverty trends by geo-type, 1997-2012: the understated role of urbanisation and social grants. Development Southern Africa 34, 151-167. 
Table 1

Stunting (\%) by province/area and year

\begin{tabular}{lrrrrr}
\hline Stunting & \multicolumn{1}{c}{ All } & & & & \\
waves & $\mathbf{2 0 0 8}$ & $\mathbf{2 0 1 0}$ & $\mathbf{2 0 1 2}$ & $\mathbf{2 0 1 4}$ \\
All Provinces & 17.1 & 16.7 & 20.7 & 19.9 & 12.4 \\
Western Cape & 11.5 & 13.1 & 15.0 & 12.7 & 7.8 \\
Eastern Cape & 21.0 & 25.8 & 26.1 & 20.3 & 14.8 \\
Northern Cape & 20.1 & 22.5 & 18.6 & 21.4 & 18.2 \\
Free State & 18.3 & 16.6 & 19.6 & 19.5 & 17.1 \\
KwaZulu-Natal & 18.3 & 16.5 & 23.3 & 20.4 & 13.8 \\
North West & 17.0 & 13.1 & 17.5 & 20.6 & 16.3 \\
Gauteng & 14.5 & 13.9 & 16.4 & 18.5 & 9.8 \\
Mpumalanga & 15.6 & 13.3 & 16.4 & 23.2 & 9.4 \\
Limpopo & 19.1 & 15.9 & 24.2 & 23.5 & 13.3 \\
Traditional & 19.8 & 18.9 & 24.0 & 23.0 & 14.3 \\
Urban & 14.9 & 14.6 & 17.6 & 17.7 & 11.0 \\
Farms & 17.6 & 19.8 & 21.1 & 15.8 & 14.1 \\
Severe stunting & & & & & \\
\hline All Provinces & 5.5 & 6.0 & 6.7 & 7.3 & 2.6 \\
Western Cape & 2.3 & 2.6 & 3.3 & 2.5 & 1.5 \\
Eastern Cape & 8.8 & 14.7 & 10.1 & 9.1 & 3.4 \\
Northern Cape & 5.1 & 4.8 & 5.4 & 6.3 & 4.1 \\
Free State & 3.6 & 2.1 & 5.1 & 4.6 & 2.6 \\
KwaZulu-Natal & 6.1 & 4.7 & 9.1 & 7.9 & 3.0 \\
North West & 5.0 & 3.0 & 6.1 & 8.9 & 2.4 \\
Gauteng & 4.2 & 4.9 & 3.7 & 6.7 & 1.8 \\
Mpumalanga & 5.5 & 5.2 & 4.4 & 9.9 & 2.1 \\
Limpopo & 5.7 & 5.5 & 6.9 & 7.3 & 3.6 \\
Traditional & 6.6 & 7.0 & 7.9 & 8.9 & 3.2 \\
Urban & 4.4 & 4.8 & 5.5 & 6.0 & 2.2 \\
Farms & 6.9 & 9.9 & 7.6 & 7.6 & 2.8 \\
\hline Note: National Income Dynamics Study (NIDS) & data \\
for participants aged & $0-19$ years & weighted using post- \\
stratification weights. & & & & & \\
& & & & & \\
& & &
\end{tabular}


Table 2

Descriptive statistics: Means and standard deviations, weighted

\begin{tabular}{|c|c|c|c|c|c|c|c|c|c|c|}
\hline \multirow[b]{2}{*}{ Variable } & \multicolumn{2}{|c|}{ All waves } & \multicolumn{2}{|c|}{ Wave 1} & \multicolumn{2}{|c|}{ Wave 2} & \multicolumn{2}{|c|}{ Wave 3} & \multicolumn{2}{|c|}{ Wave 4} \\
\hline & Mean & SD & Mean & $\mathrm{SD}$ & Mean & SD & Mean & $\mathrm{SD}$ & Mean & SD \\
\hline Stunting (yes/no) & 0.171 & 0.38 & 0.167 & 0.37 & 0.207 & 0.40 & 0.199 & 0.40 & 0.124 & 0.33 \\
\hline Severe stunting (yes/no) & 0.055 & 0.23 & 0.060 & 0.24 & 0.067 & 0.25 & 0.073 & 0.26 & 0.026 & 0.16 \\
\hline Equivalized $\mathrm{HH}$ income & 3113.908 & 6106.06 & 2391.377 & 5059.68 & 2584.396 & 4788.17 & 3187.563 & 6094.56 & 3898.244 & 7346.44 \\
\hline Real equivalized $\mathrm{HH}$ income & 3569.452 & 6865.34 & 3395.046 & 7015.40 & 3242.931 & 6012.56 & 3618.760 & 6921.25 & 3862.957 & 7225.34 \\
\hline Ln real equivalized $\mathrm{HH}$ income & 7.546 & 1.02 & 7.402 & 1.08 & 7.393 & 1.06 & 7.578 & 0.99 & 7.717 & 0.95 \\
\hline Subsistence farming (yes; ref.: no) & 0.154 & 0.36 & 0.242 & 0.43 & 0.108 & 0.31 & 0.103 & 0.30 & 0.173 & 0.38 \\
\hline \multicolumn{11}{|l|}{ Geographic classification: } \\
\hline Traditional & 0.430 & 0.50 & 0.446 & 0.50 & 0.456 & 0.50 & 0.424 & 0.49 & 0.408 & 0.49 \\
\hline Urban & 0.532 & 0.50 & 0.512 & 0.50 & 0.499 & 0.50 & 0.542 & 0.50 & 0.559 & 0.50 \\
\hline Farming & 0.038 & 0.19 & 0.042 & 0.20 & 0.045 & 0.21 & 0.034 & 0.18 & 0.033 & 0.18 \\
\hline Female & 0.503 & 0.50 & 0.502 & 0.50 & 0.510 & 0.50 & 0.499 & 0.50 & 0.501 & 0.50 \\
\hline $\mathrm{HH}$ head is female & 0.640 & 0.48 & 0.525 & 0.50 & 0.628 & 0.48 & 0.729 & 0.44 & 0.643 & 0.48 \\
\hline \multicolumn{11}{|l|}{ HH head educational level } \\
\hline No schooling & 0.169 & 0.37 & 0.212 & 0.41 & 0.213 & 0.41 & 0.149 & 0.36 & 0.127 & 0.33 \\
\hline Primary school & 0.265 & 0.44 & 0.313 & 0.46 & 0.283 & 0.45 & 0.231 & 0.42 & 0.250 & 0.43 \\
\hline Secondary school & 0.429 & 0.49 & 0.370 & 0.48 & 0.397 & 0.49 & 0.476 & 0.50 & 0.446 & 0.50 \\
\hline Higher education & 0.138 & 0.34 & 0.104 & 0.31 & 0.106 & 0.31 & 0.144 & 0.35 & 0.177 & 0.38 \\
\hline Number of employed persons in $\mathrm{HH}$ & 1.058 & 1.04 & 1.002 & 1.01 & 0.916 & 0.98 & 1.068 & 1.06 & 1.184 & 1.07 \\
\hline Access to flush toilet & 0.494 & 0.50 & 0.449 & 0.50 & 0.481 & 0.50 & 0.511 & 0.50 & 0.517 & 0.50 \\
\hline Access to tap water & 0.879 & 0.33 & 0.856 & 0.35 & 0.888 & 0.32 & 0.889 & 0.31 & 0.880 & 0.32 \\
\hline Removal of refuse and rubbish & 0.499 & 0.50 & 0.471 & 0.50 & 0.462 & 0.50 & 0.515 & 0.50 & 0.530 & 0.50 \\
\hline HH has electricity & 0.831 & 0.37 & 0.791 & 0.41 & 0.769 & 0.42 & 0.857 & 0.35 & 0.876 & 0.33 \\
\hline Race (ref.: Black) & 0.857 & 0.35 & 0.856 & 0.35 & 0.864 & 0.34 & 0.861 & 0.35 & 0.850 & 0.36 \\
\hline Coloured & 0.076 & 0.27 & 0.075 & 0.26 & 0.073 & 0.26 & 0.075 & 0.26 & 0.080 & 0.27 \\
\hline Indian/Asian & 0.018 & 0.13 & 0.020 & 0.14 & 0.017 & 0.13 & 0.016 & 0.12 & 0.019 & 0.14 \\
\hline White & 0.049 & 0.22 & 0.049 & 0.22 & 0.046 & 0.21 & 0.048 & 0.21 & 0.051 & 0.22 \\
\hline Wave 1 & 0.208 & 0.41 & 1.000 & 0.00 & 0.000 & 0.00 & 0.000 & 0.00 & 0.000 & 0.00 \\
\hline
\end{tabular}




\begin{tabular}{|c|c|c|c|c|c|c|c|c|c|c|}
\hline Wave 2 & 0.204 & 0.40 & 0.000 & 0.00 & 1.000 & 0.00 & 0.000 & 0.00 & 0.000 & 0.00 \\
\hline Wave 3 & 0.286 & 0.45 & 0.000 & 0.00 & 0.000 & 0.00 & 1.000 & 0.00 & 0.000 & 0.00 \\
\hline Wave 4 & 0.302 & 0.46 & 0.000 & 0.00 & 0.000 & 0.00 & 0.000 & 0.00 & 1.000 & 0.00 \\
\hline Western Cape & 0.084 & 0.28 & 0.066 & 0.25 & 0.077 & 0.27 & 0.090 & 0.29 & 0.095 & 0.29 \\
\hline Eastern Cape & 0.146 & 0.35 & 0.150 & 0.36 & 0.151 & 0.36 & 0.141 & 0.35 & 0.145 & 0.35 \\
\hline Northern Cape & 0.022 & 0.15 & 0.022 & 0.15 & 0.018 & 0.13 & 0.023 & 0.15 & 0.023 & 0.15 \\
\hline Free State & 0.052 & 0.22 & 0.051 & 0.22 & 0.050 & 0.22 & 0.055 & 0.23 & 0.050 & 0.22 \\
\hline KwaZulu-Natal & 0.231 & 0.42 & 0.243 & 0.43 & 0.255 & 0.44 & 0.219 & 0.41 & 0.216 & 0.41 \\
\hline North West & 0.053 & 0.22 & 0.059 & 0.23 & 0.051 & 0.22 & 0.050 & 0.22 & 0.053 & 0.22 \\
\hline Gauteng & 0.212 & 0.41 & 0.210 & 0.41 & 0.201 & 0.40 & 0.215 & 0.41 & 0.219 & 0.41 \\
\hline Mpumalanga & 0.089 & 0.29 & 0.089 & 0.29 & 0.082 & 0.27 & 0.093 & 0.29 & 0.090 & 0.29 \\
\hline Limpopo & 0.112 & 0.31 & 0.111 & 0.31 & 0.114 & 0.32 & 0.114 & 0.32 & 0.108 & 0.31 \\
\hline Number of observations & 43,314 & & 7,986 & & 8,256 & & 12,335 & & 14,737 & \\
\hline
\end{tabular}

Note: National Income Dynamics Study (NIDS) data for participants aged 0-19 years weighted using post-stratification weights. 
Table 3

Random effects logistic regression estimates on (severe) stunting: NIDS (2008-2014)

\begin{tabular}{|c|c|c|c|c|c|c|c|c|}
\hline & \multicolumn{4}{|c|}{ Stunting } & \multicolumn{4}{|c|}{ Severe stunting } \\
\hline & \multicolumn{2}{|l|}{ (1) } & \multicolumn{2}{|l|}{ (2) } & \multicolumn{2}{|l|}{ (3) } & \multicolumn{2}{|l|}{ (4) } \\
\hline & Coef & $S E$ & Coef & SE & Coef & SE & Coef & SE \\
\hline Ln real equivalized $\mathrm{HH}$ income & $-0.229 * * *$ & 0.027 & $-0.202 * * *$ & 0.028 & $-0.169 * * *$ & 0.036 & $-0.136^{* * *}$ & 0.037 \\
\hline Subsistence farming (yes; ref.: no) & $-0.178 * * *$ & 0.048 & $-0.200 * * *$ & 0.049 & $-0.347 * * *$ & 0.069 & $-0.365 * * *$ & 0.070 \\
\hline \multicolumn{9}{|l|}{ Geographic classification (ref.: urban) } \\
\hline Traditional & $0.157 * * *$ & 0.060 & $-0.161 * *$ & 0.081 & $0.136^{*}$ & 0.073 & -0.116 & 0.103 \\
\hline Farming & 0.071 & 0.096 & $-0.204 *$ & 0.106 & 0.121 & 0.118 & -0.141 & 0.134 \\
\hline \multicolumn{9}{|l|}{ Population group (ref.: African) } \\
\hline Coloured & $0.337 * * *$ & 0.098 & $0.388 * * *$ & 0.099 & $0.274 * *$ & 0.123 & $0.293 * *$ & 0.124 \\
\hline Indian /Asian & -0.327 & 0.303 & -0.159 & 0.304 & -0.692 & 0.436 & -0.557 & 0.435 \\
\hline White & $-0.561 * *$ & 0.254 & $-0.521 * *$ & 0.254 & 0.121 & 0.302 & 0.105 & 0.303 \\
\hline Female & $-0.451 * * *$ & 0.043 & $-0.449 * * *$ & 0.044 & $-0.371 * * *$ & 0.052 & $-0.371 * * *$ & 0.053 \\
\hline $\mathrm{HH}$ head is female & -0.048 & 0.041 & -0.041 & 0.041 & 0.036 & 0.055 & 0.053 & 0.056 \\
\hline \multicolumn{9}{|c|}{ HH head educational level (ref.: no schooling) } \\
\hline Primary school & -0.062 & 0.053 & -0.038 & 0.053 & 0.016 & 0.066 & 0.047 & 0.067 \\
\hline Secondary school & $-0.198 * * *$ & 0.053 & $-0.162 * * *$ & 0.054 & $-0.151 * *$ & 0.068 & -0.108 & 0.069 \\
\hline Higher education & $-0.379 * * *$ & 0.084 & $-0.334 * * *$ & 0.085 & $-0.335 * * *$ & 0.117 & $-0.294 * *$ & 0.118 \\
\hline Number of employed persons in $\mathrm{HH}$ & 0.022 & 0.021 & 0.018 & 0.022 & 0.023 & 0.029 & 0.020 & 0.029 \\
\hline Access to flush toilet & & & $-0.325 * * *$ & 0.071 & & & -0.103 & 0.094 \\
\hline Access to tap water & & & $-0.194 * * *$ & 0.054 & & & $-0.276^{* * *}$ & 0.069 \\
\hline Removal of refuse and rubbish & & & -0.063 & 0.068 & & & -0.112 & 0.094 \\
\hline $\mathrm{HH}$ has electricity & & & $-0.190 * * *$ & 0.050 & & & $-0.275^{* * *}$ & 0.063 \\
\hline Constant & $-0.571 * *$ & 0.228 & -0.098 & 0.238 & $-2.529 * * *$ & 0.304 & $-2.079 * * *$ & 0.315 \\
\hline$/ \operatorname{lnsig} 2 \mathrm{u}$ & $1.295 * * *$ & 0.046 & $1.298 * * *$ & 0.046 & $0.695 * * *$ & 0.092 & $0.702 * * *$ & 0.093 \\
\hline Number of observations & & 43,810 & & 43,314 & & 43,810 & & 43,314 \\
\hline Number of groups & & 22,328 & & 22,226 & & 22,328 & & 22,226 \\
\hline Rho & & 0.526 & & 0.527 & & 0.378 & & 0.380 \\
\hline sigma_u & & 1.911 & & 1.914 & & 1.415 & & 1.420 \\
\hline $\mathrm{Chi}^{2}$ & & 759.172 & & 804.423 & & 505.601 & & 540.345 \\
\hline Degrees of freedom & & 24 & & 28 & & 24 & & 28 \\
\hline
\end{tabular}




\section{Hohenheim Discussion Papers in Business, Economics and Social Sciences}

The Faculty of Business, Economics and Social Sciences continues since 2015 the established "FZID Discussion Paper Series" of the "Centre for Research on Innovation and Services (FZID)" under the name "Hohenheim Discussion Papers in Business, Economics and Social Sciences".

\section{Institutes}

$510 \quad$ Institute of Financial Management

520 Institute of Economics

530 Institute of Health Care \& Public Management

540 Institute of Communication Science

550 Institute of Law and Social Sciences

560 Institute of Economic and Business Education

570 Institute of Marketing \& Management

580 Institute of Interorganisational Management \& Performance

\section{Research Areas (since 2017)}

INEPA "Inequality and Economic Policy Analysis"

TKID "Transformation der Kommunikation - Integration und Desintegration"

NegoTrans "Negotiation Research - Transformation, Technology, Media and Costs"

INEF "Innovation, Entrepreneurship and Finance"

Download Hohenheim Discussion Papers in Business, Economics and Social Sciences from our homepage: https://wiso.uni-hohenheim.de/papers

\section{No. Author \\ 01-2015 Thomas Beissinger, Philipp Baudy}

02-2015 Fabian Wahl

03-2015 Tommaso Proietti, Martyna Marczak, Gianluigi Mazzi

04-2015 Thomas Beissinger, Nathalie Chusseau, Joël Hellier

05-2015 Matthias Mueller, Kristina Bogner, Tobias Buchmann, Muhamed Kudic

06-2015 Martyna Marczak, Thomas Beissinger

07-2015 Peng Nie, Galit Nimrod, Alfonso Sousa-Poza
Title Inst

THE IMPACT OF TEMPORARY AGENCY WORK 520 ON TRADE UNION WAGE SETTING:

A Theoretical Analysis

PARTICIPATIVE POLITICAL INSTITUTIONS AND CITY DEVELOPMENT 800-1800

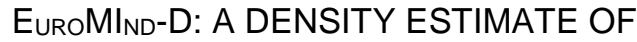
MONTHLY GROSS DOMESTIC PRODUCT FOR THE EURO AREA

OFFSHORING AND LABOUR MARKET REFORMS: MODELLING THE GERMAN EXPERIENCE

SIMULATING KNOWLEDGE DIFFUSION IN FOUR 520 STRUCTURALLY DISTINCT NETWORKS - AN AGENT-BASED SIMULATION MODEL

BIDIRECTIONAL RELATIONSHIP BETWEEN 520 INVESTOR SENTIMENT AND EXCESS RETURNS: NEW EVIDENCE FROM THE WAVELET PERSPECTIVE

INTERNET USE AND SUBJECTIVE WELL-BEING IN CHINA 
No. Author

Title

Inst

08-2015 Fabian Wahl

09-2015 Peng Nie, Alfonso Sousa-Poza

10-2015 Kristina Bogner

11-2015 Bogang Jun, Tai-Yoo Kim

12-2015 Volker Grossmann Aderonke Osikominu Marius Osterfeld

13-2015 Martyna Marczak Tommaso Proietti Stefano Grassi

14-2015 Carolina Castagnetti Luisa Rosti Marina Töpfer

15-2015 Alexander Opitz

01-2016 Michael Ahlheim, Jan Neidhardt

02-2016 Bogang Jun, Alexander Gerybadze, Tai-Yoo Kim

03-2016 Peng Nie, Alfonso Sousa-Poza

04-2016 Peter Spahn

05-2016 Vincent Dekker, Kristina Strohmaier, Nicole Bosch

06-2016 Philipp Baudy, Dario Cords
THE LONG SHADOW OF HISTORY

ROMAN LEGACY AND ECONOMIC DEVELOPMENT

520

- EVIDENCE FROM THE GERMAN LIMES

COMMUTE TIME AND SUBJECTIVE WELL-BEING IN URBAN CHINA

530

THE EFFECT OF PROJECT FUNDING ON INNOVATIVE PERFORMANCE AN AGENT-BASED SIMULATION MODEL

520

A NEO-SCHUMPETERIAN PERSPECTIVE ON THE ANALYTICAL MACROECONOMIC FRAMEWORK: THE EXPANDED REPRODUCTION SYSTEM

ARE SOCIOCULTURAL FACTORS IMPORTANT FOR STUDYING A SCIENCE UNIVERSITY MAJOR?

520

A DATA-CLEANING AUGMENTED KALMAN FILTER FOR ROBUST ESTIMATION OF STATE SPACE MODELS

520

THE REVERSAL OF THE GENDER PAY GAP AMONG PUBLIC-CONTEST SELECTED YOUNG EMPLOYEES

520

DEMOCRATIC PROSPECTS IN IMPERIAL RUSSIA: THE REVOLUTION OF 1905 AND THE POLITICAL STOCK MARKET

NON-TRADING BEHAVIOUR IN CHOICE EXPERIMENTS

THE LEGACY OF FRIEDRICH LIST: THE EXPANSIVE REPRODUCTION SYSTEM AND THE KOREAN HISTORY OF INDUSTRIALIZATION

FOOD INSECURITY AMONG OLDER EUROPEANS: 530 EVIDENCE FROM THE SURVEY OF HEALTH, AGEING, AND RETIREMENT IN EUROPE

POPULATION GROWTH, SAVING, INTEREST RATES AND STAGNATION. DISCUSSING THE EGGERTSSONMEHROTRA-MODEL

A DATA-DRIVEN PROCEDURE TO DETERMINE THE BUNCHING WINDOW - AN APPLICATION TO THE NETHERLANDS

DEREGULATION OF TEMPORARY AGENCY EMPLOYMENT IN A UNIONIZED ECONOMY: DOES THIS REALLY LEAD TO A SUBSTITUTION OF REGULAR EMPLOYMENT? 
No.

07-2016

Robin Jessen, Davud Rostam-Afschar, Sebastian Schmitz

08-2016 Peng Nie, Alfonso Sousa-Poza, Jianhong Xue

09-2016 Bogang Jun, Seung Kyu-Yi, Tobias Buchmann, Matthias Müller

10-2016 Vladan Ivanovic, Vadim Kufenko, Boris Begovic Nenad Stanisic, Vincent Geloso

11-2016 David E. Bloom Michael Kuhn Klaus Prettner

12-2016 Franz X. Hof Klaus Prettner

13-2016 Jung-In Yeon Andreas Pyka Tai-Yoo Kim

14-2016 Benjamin Fuchs

15-2016 Seung-Kyu Yi Bogang Jun

16-2016 Gregor Pfeifer Fabian Wahl Martyna Marczak

17-2016 Malte Klein Andreas Sauer

18-2016 Klaus Prettner

19-2016 Klaus Prettner Andreas Schaefer

20-2016 Vadim Kufenko Klaus Prettner
Title

Inst

HOW IMPORTANT IS PRECAUTIONARY LABOR

520 SUPPLY?

FUEL FOR LIFE: DOMESTIC COOKING FUELS AND 530 WOMEN'S HEALTH IN RURAL CHINA

THE CO-EVOLUTION OF INNOVATION NETWORKS: 520 COLLABORATION BETWEEN WEST AND EAST GERMANY FROM 1972 TO 2014

CONTINUITY UNDER A DIFFERENT NAME. 520 THE OUTCOME OF PRIVATISATION IN SERBIA

THE CONTRIBUTION OF FEMALE HEALTH TO ECONOMIC DEVELOPMENT GROWTH

STRUCTURAL SHIFT AND INCREASING VARIETY IN KOREA, 1960-2010: EMPIRICAL EVIDENCE OF THE ECONOMIC DEVELOPMENT MODEL BY THE CREATION OF NEW SECTORS

THE EFFECT OF TEENAGE EMPLOYMENT ON CHARACTER SKILLS, EXPECTATIONS AND OCCUPATIONAL CHOICE STRATEGIES

HAS THE GERMAN REUNIFICATION 520 STRENGTHENED GERMANY'S NATIONAL INNOVATION SYSTEM? TRIPLE HELIX DYNAMICS OF GERMANY'S INNOVATION SYSTEM

ILLUMINATING THE WORLD CUP EFFECT: NIGHT LIGHTS EVIDENCE FROM SOUTH AFRICA

CELEBRATING 30 YEARS OF INNOVATION 570 SYSTEM RESEARCH: WHAT YOU NEED TO KNOW ABOUT INNOVATION SYSTEMS

THE IMPLICATIONS OF AUTOMATION FOR ECONOMIC GROWTH AND THE LABOR SHARE

HIGHER EDUCATION AND THE FALL AND RISE OF INEQUALITY

520

YOU CAN'T ALWAYS GET WHAT YOU WANT? 520 ESTIMATOR CHOICE AND THE SPEED OF CONVERGENCE 
No.

\section{Author}

Title

CHILDRENS HEALTH, HUMAN CAPITAL ACCUMULATION, AND R\&D-BASED ECONOMIC Alberto Bucci Klaus Prettner

02-2017 Julius Tennert Marie Lambert Hans-Peter Burghof

03-2017 Michael Ahlheim Oliver Frör Nguyen Minh Duc Antonia Rehl Ute Siepmann Pham Van Dinh

04-2017 Bohdan Kukharskyy Sebastian Seiffert

05-2017 Ana Abeliansky Klaus Prettner

06-2017 Vincent Geloso Vadim Kufenko

07-2017 Emanuel Gasteiger Klaus Prettner

08-2017 Klaus Prettner Holger Strulik

09-2017 David E. Bloom Simiao Chen Michael Kuhn Mark E. McGovern Les Oxley Klaus Prettner

10-2017 Sebastian Till Braun Nadja Dwenger

11-2017 Vadim Kufenko Klaus Prettner Vincent Geloso

12-2017 Frank M. Fossen Ray Rees Davud Rostam-Afschar Viktor Steiner

13-2017 Steffen Otterbach Michael Rogan HOUSEHOLD AGRICULTURAL PRODUCTION IN GROWTH

MORAL HAZARD IN VC-FINANCE: MORE

INEF EXPENSIVE THAN YOU THOUGHT

LABOUR AS A UTILITY MEASURE RECONSIDERED 520

GUN VIOLENCE IN THE U.S.: CORRELATES AND CAUSES

AUTOMATION AND DEMOGRAPHIC CHANGE

520

INEQUALITY AND GUARD LABOR, OR

INEPA

PROHIBITION AND GUARD LABOR?

ON THE POSSIBILITY OF AUTOMATION-INDUCED STAGNATION

520

THE LOST RACE AGAINST THE MACHINE: AUTOMATION, EDUCATION, AND INEQUALITY IN AN R\&D-BASED GROWTH MODEL

THE ECONOMIC BURDEN OF CHRONIC DISEASES: ESTIMATES AND PROJECTIONS FOR CHINA, JAPAN, AND SOUTH KOREA

THE LOCAL ENVIRONMENT SHAPES REFUGEE INTEGRATION: EVIDENCE FROM POST-WAR GERMANY

DIVERGENCE, CONVERGENCE, AND THE HISTORY-AUGMENTED SOLOW MODEL

INEPA

HOW DO ENTREPRENEURIAL PORTFOLIOS 520 RESPOND TO INCOME TAXATION?

INEPA

SPATIAL DIFFERENCES IN STUNTING AND INEPA SOUTH AFRICA: (RE-) EXAMINING THE LINKS USING NATIONAL PANEL SURVEY DATA 
(published 2009-2014)

\section{Competence Centers}

IK Innovation and Knowledge

ICT Information Systems and Communication Systems

CRFM Corporate Finance and Risk Management

$\mathrm{HCM} \quad$ Health Care Management

CM Communication Management

MM Marketing Management

ECO Economics

Download FZID Discussion Papers from our homepage: https://wiso.uni-hohenheim.de/archiv_fzid_papers

\begin{tabular}{|c|c|c|c|}
\hline Nr. & Autor & Titel & CC \\
\hline 01-2009 & Julian P. Christ & $\begin{array}{l}\text { NEW ECONOMIC GEOGRAPHY RELOADED: } \\
\text { Localized Knowledge Spillovers and the Geography of Innovation }\end{array}$ & IK \\
\hline 02-2009 & André P. Slowak & $\begin{array}{l}\text { MARKET FIELD STRUCTURE \& DYNAMICS IN INDUSTRIAL } \\
\text { AUTOMATION }\end{array}$ & IK \\
\hline 03-2009 & $\begin{array}{l}\text { Pier Paolo Saviotti, } \\
\text { Andreas Pyka }\end{array}$ & $\begin{array}{l}\text { GENERALIZED BARRIERS TO ENTRY AND ECONOMIC } \\
\text { DEVELOPMENT }\end{array}$ & IK \\
\hline 04-2009 & $\begin{array}{l}\text { Uwe Focht, Andreas } \\
\text { Richter and Jörg } \\
\text { Schiller }\end{array}$ & INTERMEDIATION AND MATCHING IN INSURANCE MARKETS & $\mathrm{HCM}$ \\
\hline 05-2009 & $\begin{array}{l}\text { Julian P. Christ, } \\
\text { André P. Slowak }\end{array}$ & $\begin{array}{l}\text { WHY BLU-RAY VS. HD-DVD IS NOT VHS VS. BETAMAX: } \\
\text { THE CO-EVOLUTION OF STANDARD-SETTING CONSORTIA }\end{array}$ & $\mathrm{IK}$ \\
\hline 06-2009 & $\begin{array}{l}\text { Gabriel Felbermayr, } \\
\text { Mario Larch and } \\
\text { Wolfgang Lechthaler }\end{array}$ & UNEMPLOYMENT IN AN INTERDEPENDENT WORLD & $\mathrm{ECO}$ \\
\hline 07-2009 & Steffen Otterbach & $\begin{array}{l}\text { MISMATCHES BETWEEN ACTUAL AND PREFERRED WORK } \\
\text { TIME: Empirical Evidence of Hours Constraints in } 21 \text { Countries }\end{array}$ & $\mathrm{HCM}$ \\
\hline 08-2009 & Sven Wydra & $\begin{array}{l}\text { PRODUCTION AND EMPLOYMENT IMPACTS OF NEW } \\
\text { TECHNOLOGIES - ANALYSIS FOR BIOTECHNOLOGY }\end{array}$ & IK \\
\hline 09-2009 & $\begin{array}{l}\text { Ralf Richter, } \\
\text { Jochen Streb }\end{array}$ & $\begin{array}{l}\text { CATCHING-UP AND FALLING BEHIND } \\
\text { KNOWLEDGE SPILLOVER FROM AMERICAN } \\
\text { TO GERMAN MACHINE TOOL MAKERS }\end{array}$ & IK \\
\hline
\end{tabular}


Nr.

Autor

Titel

CC

KYOTO AND THE CARBON CONTENT OF TRADE

ECO

Gabriel Felbermayr

11-2010 David E. Bloom,

ECONOMIC CONSEQUENCES OF LOW FERTILITY IN EUROPE

$\mathrm{HCM}$

Alfonso Sousa-Poza

12-2010 Michael Ahlheim, Oliver Frör

DRINKING AND PROTECTING - A MARKET APPROACH TO THE PRESERVATION OF CORK OAK LANDSCAPES

ECO

LABOUR AS A UTILITY MEASURE IN CONTINGENT VALUATION STUDIES - HOW GOOD IS IT REALLY?

ECO

Oliver Frör,

Antonia Heinke,

Nguyen Minh Duc,

and Pham Van Dinh

14-2010 Julian P. Christ

THE GEOGRAPHY AND CO-LOCATION OF EUROPEAN

IK

TECHNOLOGY-SPECIFIC CO-INVENTORSHIP NETWORKS

15-2010 Harald Degner

WINDOWS OF TECHNOLOGICAL OPPORTUNITY

DO TECHNOLOGICAL BOOMS INFLUENCE THE RELATIONSHIP BETWEEN FIRM SIZE AND INNOVATIVENESS?

16-2010 Tobias A. Jopp

THE WELFARE STATE EVOLVES:

GERMAN KNAPPSCHAFTEN, 1854-1923

$\mathrm{HCM}$

17-2010 Stefan Kirn (Ed.)

PROCESS OF CHANGE IN ORGANISATIONS THROUGH

ICT

eHEALTH

18-2010 Jörg Schiller

ÖKONOMISCHE ASPEKTE DER ENTLOHNUNG

$\mathrm{HCM}$

UND REGULIERUNG UNABHÄNGIGER

VERSICHERUNGSVERMITTLER

19-2010 Frauke Lammers,

CONTRACT DESIGN AND INSURANCE FRAUD: AN

$\mathrm{HCM}$

Jörg Schiller

EXPERIMENTAL INVESTIGATION

REAL WAGES AND THE BUSINESS CYCLE IN GERMANY

ECO

Thomas Beissinger

21-2010 Harald Degner,

Jochen Streb

FOREIGN PATENTING IN GERMANY, 1877-1932

IK

DOES DOWNWARD NOMINAL WAGE RIGIDITY

ECO

Thomas Beissinger

DAMPEN WAGE INCREASES?

GUNS AND BUTTER - BUT NO MARGARINE: THE IMPACT OF NAZI ECONOMIC POLICIES ON GERMAN FOOD

ECO Jochen Streb 
Nr.

Autor

Titel

24-2011 Dhammika Dharmapala, Nadine Riedel

25-2011 Michael Schuele, Stefan Kirn

26-2011 Marcus Müller, Guillaume Stern, Ansger Jacob and Stefan Kirn

27-2011 Monnet Benoit, Patrick Gbakoua and Alfonso Sousa-Poza

28-2011 Nadine Riedel, Hannah SchildbergHörisch

29-2011 Nicole Waidlein

30-2011 Dominik Hartmann, Atilio Arata

31-2011 Peter Spahn

32-2011 Fabian Wahl

33-2011 Giorgio Triulzi, Ramon Scholz and Andreas Pyka

34-2011 Claus D. MüllerHengstenberg, Stefan Kirn

35-2011 Andreas Pyka

36-2011 David Bell, Steffen Otterbach and Alfonso Sousa-Poza

37-2011 Lukas Scheffknecht, Felix Geiger

38-2011 Yin Krogmann, Ulrich Schwalbe
EARNINGS SHOCKS AND TAX-MOTIVATED INCOME-SHIFTING: EVIDENCE FROM EUROPEAN MULTINATIONALS

ECO

ICT

QUALITATIVES, RÄUMLICHES SCHLIEßEN ZUR KOLLISIONSERKENNUNG UND KOLLISIONSVERMEIDUNG AUTONOMER BDI-AGENTEN

VERHALTENSMODELLE FÜR SOFTWAREAGENTEN IM ICT PUBLIC GOODS GAME

ECO

ENGEL CURVES, SPATIAL VARIATION IN PRICES AND

DEMAND FOR COMMODITIES IN CÔTE D'IVOIRE

ASYMMETRIC OBLIGATIONS

ECO

CAUSES OF PERSISTENT PRODUCTIVITY DIFFERENCES IN THE WEST GERMAN STATES IN THE PERIOD FROM 1950 TO 1990

MEASURING SOCIAL CAPITAL AND INNOVATION IN POOR AGRICULTURAL COMMUNITIES. THE CASE OF CHÁPARRA PERU

DIE WÄHRUNGSKRISENUNION

DIE EURO-VERSCHULDUNG DER NATIONALSTAATEN ALS SCHWACHSTELLE DER EWU

ECO

DIE ENTWICKLUNG DES LEBENSSTANDARDS IM DRITTEN REICH - EINE GLÜCKSÖKONOMISCHE PERSPEKTIVE

ECO

R\&D AND KNOWLEDGE DYNAMICS IN UNIVERSITY-INDUSTRY

IK RELATIONSHIPS IN BIOTECH AND PHARMACEUTICALS: AN AGENT-BASED MODEL

ANWENDUNG DES ÖFFENTLICHEN VERGABERECHTS AUF MODERNE IT SOFTWAREENTWICKLUNGSVERFAHREN

ICT

AVOIDING EVOLUTIONARY INEFFICIENCIES

IK IN INNOVATION NETWORKS

WORK HOURS CONSTRAINTS AND HEALTH

$\mathrm{HCM}$

A BEHAVIORAL MACROECONOMIC MODEL WITH

ECO ENDOGENOUS BOOM-BUST CYCLES AND LEVERAGE DYNAMICS

INTER-FIRM R\&D NETWORKS IN THE GLOBAL PHARMACEUTICAL BIOTECHNOLOGY INDUSTRY DURING 1985-1998: A CONCEPTUAL AND EMPIRICAL ANALYSIS 
Nr.

39-2011 Michael Ahlheim, Tobias Börger and Oliver Frör

40-2011 Tobias Börger

41-2011 Ralf Rukwid, Julian P. Christ
RESPONDENT INCENTIVES IN CONTINGENT VALUATION: THE ECO ROLE OF RECIPROCITY

A DIRECT TEST OF SOCIALLY DESIRABLE RESPONDING IN CONTINGENT VALUATION INTERVIEWS

ECO

QUANTITATIVE CLUSTERIDENTIFIKATION AUF EBENE

IK DER DEUTSCHEN STADT- UND LANDKREISE (1999-2008) 
Nr.

Autor

Titel

42-2012 Benjamin Schön,

A TAXONOMY OF INNOVATION NETWORKS

IK

Andreas Pyka

43-2012 Dirk Foremny, Nadine Riedel

BUSINESS TAXES AND THE ELECTORAL CYCLE

ECO

44-2012 Gisela Di Meglio, Andreas Pyka and

VARIETIES OF SERVICE ECONOMIES IN EUROPE

IK

Luis Rubalcaba

45-2012 Ralf Rukwid, Julian P. Christ

INNOVATIONSPOTENTIALE IN BADEN-WÜRTTEMBERG:

IK

PRODUKTIONSCLUSTER IM BEREICH „METALL, ELEKTRO, IKT“ UND REGIONALE VERFÜGBARKEIT AKADEMISCHER FACHKRÄFTE IN DEN MINT-FÄCHERN

46-2012 Julian P. Christ,

INNOVATIONSPOTENTIALE IN BADEN-WÜRTTEMBERG:

IK Ralf Rukwid BRANCHENSPEZIFISCHE FORSCHUNGS- UND ENTWICKLUNGSAKTIVITÄT, REGIONALES PATENTAUFKOMMEN UND BESCHÄFTIGUNGSSTRUKTUR

47-2012 Oliver Sauter

ASSESSING UNCERTAINTY IN EUROPE AND THE

ECO US - IS THERE A COMMON FACTOR?

IK

SEN MEETS SCHUMPETER. INTRODUCING STRUCTUR
DYNAMIC ELEMENTS INTO THE HUMAN CAPABILITY APPROACH

49-2012 Harold ParedesFrigolett, Andreas Pyka

DISTAL EMBEDDING AS A TECHNOLOGY INNOVATION

IK NETWORK FORMATION STRATEGY

CYCLICALITY OF REAL WAGES IN THE USA AND GERMANY: NEW INSIGHTS FROM WAVELET ANALYSIS

ECO

Martyna Marczak Víctor Gómez

DIE DURCHSETZUNG VON SCHNITTSTELLEN

IK IN DER STANDARDSETZUNG:

FALLBEISPIEL LADESYSTEM ELEKTROMOBILITÄT

52-2012 Fabian Wahl

WHY IT MATTERS WHAT PEOPLE THINK - BELIEFS, LEGAL

ECO ORIGINS AND THE DEEP ROOTS OF TRUST

IK

Micha Kaiser

STATISTISCHER ÜBERBLICK DER TÜRKISCHEN MIGRATION IN BADEN-WÜRTTEMBERG UND DEUTSCHLAND

IDENTIFIZIERUNG UND ANALYSE DEUTSCH-TÜRKISCHER INNOVATIONSNETZWERKE. ERSTE ERGEBNISSE DES TGIN-

Andreas Pyka, Seda Aydin, Lena Klauß, Fabian Stahl, Ali PROJEKTES

Santircioglu, Silvia Oberegelsbacher, Sheida Rashidi, Gaye Onan and Suna Erginkoç

55-2012 Michael Ahlheim, Tobias Börger and Oliver Frör DESERT: A CONTINGENT VALUATION STUDY IN RURAL SOUTHWEST CHINA 
Nr. Autor

56-2012 Matthias Strifler Thomas Beissinger

57-2012 Peter Spahn

58-2012 Sibylle H. Lehmann

59-2012 Sibylle H. Lehmann, Philipp Hauber and Alexander Opitz

60-2012 Martyna Marczak, Víctor Gómez

61-2012 Theresa Lohse, Nadine Riedel
FAIRNESS CONSIDERATIONS IN LABOR UNION WAGE SETTING - A THEORETICAL ANALYSIS

INTEGRATION DURCH WÄHRUNGSUNION? DER FALL DER EURO-ZONE

TAKING FIRMS TO THE STOCK MARKET:

IPOS AND THE IMPORTANCE OF LARGE BANKS IN IMPERIAL GERMANY 1896-1913

POLITICAL RIGHTS, TAXATION, AND FIRM VALUATION -

ECO EVIDENCE FROM SAXONY AROUND 1900

SPECTRAN, A SET OF MATLAB PROGRAMS FOR SPECTRAL

ECO ANALYSIS

THE IMPACT OF TRANSFER PRICING REGULATIONS ON PROFIT SHIFTING WITHIN EUROPEAN MULTINATIONALS
ECO

ECO

ECO

ECO 
Nr. Autor

63-2013 David E. Bloom,

AGEING AND PRODUCTIVITY

$\mathrm{HCM}$

Alfonso Sousa-Poza

64-2013 Martyna Marczak,

MONTHLY US BUSINESS CYCLE INDICATORS:

ECO Víctor Gómez

A NEW MULTIVARIATE APPROACH BASED ON A BAND-PASS FILTER

65-2013 Dominik Hartmann,

INNOVATION, ECONOMIC DIVERSIFICATION AND HUMAN

IK

Andreas Pyka

DEVELOPMENT

66-2013 Christof Ernst,

CORPORATE TAXATION AND THE QUALITY OF RESEARCH

ECO

Katharina Richter and AND DEVELOPMENT

Nadine Riede

67-2013 Michael Ahlheim, Oliver Frör, Jiang Tong, Luo Jing and Sonna Pelz

68-2013 Michael Ahlheim, Friedrich Schneider

CONSIDERING HOUSEHOLD SIZE IN CONTINGENT VALUATION STUDIES

69-2013 Fabio Bertoni, Tereza Tykvová

WHICH FORM OF VENTURE CAPITAL IS MOST SUPPORTIVE OF INNOVATION?

EVIDENCE FROM EUROPEAN BIOTECHNOLOGY COMPANIES

70-2013 Tobias Buchmann, Andreas Pyka

THE EVOLUTION OF INNOVATION NETWORKS:

THE CASE OF A GERMAN AUTOMOTIVE NETWORK Pyka, J. A. La Poutré and A. G. de Kok

72-2013 Beatriz Fabiola López Ulloa, Valerie Møller and Alfonso SousaPoza

73-2013 Wencke Gwozdz, Alfonso Sousa-Poza, Lucia A. Reisch, Wolfgang Ahrens, Stefaan De Henauw, Gabriele Eiben, Juan M. Fernández-Alvira, Charalampos Hadjigeorgiou, Eva Kovács, Fabio Lauria, Toomas Veidebaum, Garrath Williams, Karin Bammann

HOW DOES SUBJECTIVE WELL-BEING EVOLVE WITH AGE? 
Nr.

Autor

74-2013 Andreas Haas, Annette Hofmann

75-2013 Yin Krogmann, Nadine Riedel and Ulrich Schwalbe

76-2013 Peter Spahn

77-2013 Sheida Rashidi, Andreas Pyka

78-2013 Benjamin Schön, Andreas Pyka

79-2013 Irene Prostolupow, Andreas Pyka and Barbara Heller-Schuh

80-2013 Eva Schlenker, Kai D. Schmid

81-2013 Michael Ahlheim, Tobias Börger and Oliver Frör

82-2013 Fabian Wahl

83-2013 Peter Spahn

84-2013 Daniel Guffarth, Michael J. Barber
RISIKEN AUS CLOUD-COMPUTING-SERVICES:

$\mathrm{HCM}$ FRAGEN DES RISIKOMANAGEMENTS UND ASPEKTE DER VERSICHERBARKEIT

INTER-FIRM R\&D NETWORKS IN PHARMACEUTICAL

ECO, IK BIOTECHNOLOGY: WHAT DETERMINES FIRM'S CENTRALITY-BASED PARTNERING CAPABILITY?

MACROECONOMIC STABILISATION AND BANK LENDING:

ECO A SIMPLE WORKHORSE MODEL

MIGRATION AND INNOVATION - A SURVEY

IK

THE SUCCESS FACTORS OF TECHNOLOGY-SOURCING THROUGH MERGERS \& ACQUISITIONS - AN INTUITIVE METAANALYSIS

TURKISH-GERMAN INNOVATION NETWORKS IN THE EUROPEAN RESEARCH LANDSCAPE

IK

ECO

CAPITAL INCOME SHARES AND INCOME INEQUALITY IN THE EUROPEAN UNION

ECO

THE INFLUENCE OF ETHNICITY AND CULTURE ON THE VALUATION OF ENVIRONMENTAL IMPROVEMENTS - RESULTS FROM A CVM STUDY IN SOUTHWEST CHINA -

DOES MEDIEVAL TRADE STILL MATTER? HISTORICAL TRADE CENTERS, AGGLOMERATION AND CONTEMPORARY ECONOMIC DEVELOPMENT

SUBPRIME AND EURO CRISIS: SHOULD WE BLAME THE ECO ECONOMISTS?

THE EUROPEAN AEROSPACE R\&D COLLABORATION

IK NETWORK

KARTELLBEKÄMPFUNG UND INTERNE KARTELLSTRUKTUREN

IK EIN NETZWERKTHEORETISCHER ANSATZ 
Nr.

Autor

86-2014 Stefan Kirn, Claus D.

INTELLIGENTE (SOFTWARE-)AGENTEN: EINE NEUE

ICT Müller-Hengstenberg HERAUSFORDERUNG FÜR DIE GESELLSCHAFT UND UNSER RECHTSSYSTEM?

87-2014 Peng Nie, Alfonso

MATERNAL EMPLOYMENT AND CHILDHOOD OBESITY IN $\mathrm{HCM}$ Sousa-Poza CHINA: EVIDENCE FROM THE CHINA HEALTH AND NUTRITION SURVEY

88-2014 Steffen Otterbach, Alfonso Sousa-Poza

JOB INSECURITY, EMPLOYABILITY, AND HEALTH:

$\mathrm{HCM}$ AN ANALYSIS FOR GERMANY ACROSS GENERATIONS

89-2014 Carsten Burhop, Sibylle H. LehmannHasemeyer

THE GEOGRAPHY OF STOCK EXCHANGES IN IMPERIAL GERMANY

ECO

90-2014 Martyna Marczak, OUTLIER DETECTION IN STRUCTURAL TIME SERIES Tommaso Proietti MODELS: THE INDICATOR SATURATION APPROACH

Andreas Pyka

92-2014 Bogang Jun, Joongho Lee

THE TRADEOFF BETWEEN FERTILITY AND EDUCATION: EVIDENCE FROM THE KOREAN DEVELOPMENT PATH

NON-FINANCIAL HURDLES FOR HUMAN CAPITAL ACCUMULATION: LANDOWNERSHIP IN KOREA UNDER JAPANESE RULE

94-2014 Michael Ahlheim, Oliver Frör, Gerhard Langenberger and Sonna Pelz

95-2014 Harold ParedesFrigolett, Andreas Pyka, Javier Pereira and Luiz Flávio Autran Monteiro Gomes

CHINESE URBANITES AND THE PRESERVATION OF RARE SPECIES IN REMOTE PARTS OF THE COUNTRY - THE EXAMPLE OF EAGLEWOOD

IK

IK

RANKING THE PERFORMANCE OF NATIONAL INNOVATION SYSTEMS IN THE IBERIAN PENINSULA AND LATIN AMERICA FROM A NEO-SCHUMPETERIAN ECONOMICS PERSPECTIVE

96-2014 Daniel Guffarth, Michael J. Barber 


\section{IMPRINT}

University of Hohenheim

Dean's Office of the Faculty of Business, Economics and Social Sciences Palace Hohenheim $1 \mathrm{~B}$

70593 Stuttgart | Germany

Fon $\quad+49(0) 71145922488$

Fax $\quad+49(0) 71145922785$

E-mail wiso@uni-hohenheim.de

Web www.wiso.uni-hohenheim.de 